\begin{tabular}{|c|c|c|}
\hline()$_{\text {SiiRT }}^{\prime}$ & $\begin{array}{c}\text { Türkiye Tarımsal Araştırmalar Dergisi } \\
\text { dergipark.org.tr/tutad }\end{array}$ & $\begin{array}{l}\text { Turk J Agric Res } \\
\text { 2019, 6(3): 242-256 } \\
\text { ○ TÜTAD } \\
\text { ISSN: 2148-2306 }\end{array}$ \\
\hline 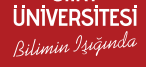 & Araştırma Makalesi / Research Article & $\begin{array}{l}\text { e-ISSN: } 2528-858 X \\
\text { doi: } 10.19159 / \text { tutad.502457 }\end{array}$ \\
\hline
\end{tabular}

\title{
Erozyon Duyarlılık Parametrelerinin Farklı Enterpolasyon Yöntemleriyle Konumsal Dağılımlarının Belirlenmesi: Türkiye, Ilgaz Milli Park Toprakları*
}

\author{
Celalledin CELİLOV, Orhan DENGIZ** \\ Ondokuz Mayıs Üniversitesi, Ziraat Fakültesi, Toprak Bilimi ve Bitki Besleme Bölümü, Samsun, TÜRKIYY
}

\begin{tabular}{ll}
\hline \multicolumn{1}{c}{ Geliş Tarihi/Received: 25.12 .2018} & Kabul Tarihi/Accepted: 26.09 .2019 \\
\hline ORCID ID (Yazar surasina göre / by author order) & \\
(D)orcid.org/0000-0003-0752-0175 (Dorcid.org/0000-0002-0458-6016 & \\
"Sorumlu Yazar/Corresponding Author: dengizorhan@gmail.com &
\end{tabular}

Öz: Bu çalışmanın amacı, Ilgaz Milli Park sınırları içerisinde dağılım gösteren toprakların; toprak aşınım faktörü (USLE-K), dispersiyon oranı ve kil oranı gibi bazı erozyon duyarlılık parametrelerinin belirlenmesi ve Coğrafi Bilgi Sistemleri yardımıyla farklı enterpolasyon yöntemleri kullanılarak konumsal dağılımlarının haritalanmasıdır. Bu amaçla, çalışma alanından rastgele örnekleme yöntemiyle 0-20 cm toprak derinliğinden 151 adet toprak örneği alınmıştır. Elde edilen sonuçlara göre, araştırma alanı topraklarının büyük bir kısmının erozyona karșı oldukça yüksek duyarlı olduğu belirlenmiștir. Ayrıca, duyarlılık parametreleri ile toprakların diğer fiziksel ve kimyasal özellikleri arasındaki korelasyon analizi sonucuna göre; USLE-K ile organik madde, kireç, kil ve silt arasında $\mathrm{p}<0.01$ önem düzeyinde negatif ilişki belirlenirken, hacim ağırlığı ve kum arasında $\mathrm{p}<0.01$ önem düzeyinde pozitif ilişki görülmüştür. Bu duruma yönelik olarak benzer sonuçlar kil haricinde dispersiyon oranında da belirlenmiştir. Kil oranı yönünden, organik madde ile herhangi bir ilişki görülmezken, kil ve silt ile $p<0.05$ önem düzeyinde negatif, kum ile pozitif ilişki belirlenmiştir. Sonuç olarak, araştırma alanı topraklarının büyük bir kısmının erozyona karşı duyarlılıkları oldukça yüksek olması nedeniyle, organik madde kapsamını ve hidrolik geçirgenliğini arttırıcı ve strüktürünü geliştirici önlemlerin alınmasının yanı sıra, üzerinde yer alan bitki örtüsünün tahrip edilmemesi de gerekmektedir.

Anahtar Kelimeler: Kil oran1, dispersiyon oran1, USLE-K, enterpolasyon, Ilgaz Milli Park1

\section{Determination of the Spatial Distribution for Erodibility Parameters Using Different Interpolation Methods: Ilgaz National Park Soils, Turkey}

\begin{abstract}
The aim of this study is to determine some erosion susceptibility parameters such as soil erosion factor (USLE-K), dispersion rate and clay ratio of the soils distributed within the Ilgaz National Park and map their spatial distributions using different interpolation methods with the help of Geographic Information Systems. For this aim, a total of 151 soil samples were collected from 0-20 cm soil depth using random sampling method. According to obtained results, it was determined that most part of the investigated soils has high erodobility value. In addition, according to the correlation analysis between sensitivity parameters and other physical and chemical properties of soils; A negative correlation was detected between USLE$\mathrm{K}$ and organic matter, lime, clay, and silt at a significance level of $\mathrm{p}<0.01$, a positive correlation was found between bulk density and sand at a significance level of $\mathrm{p}<0.01$. Similar case was also found for DR except for clay. In terms of clay content, there was no relationship with organic matter, but a negative correlation with $\mathrm{p}<0.05$ significance with sand and silt, and a positive correlation with sand was found. As a result, due to high erosion sensitivity of a large part of the research area soils, it is necessary to take measures to increase the organic matter content and hydraulic permeability and improve its structure, as well as to protect the vegetation on the soil.
\end{abstract}

Keywords: Clay ratio, dispersion ratio, USLE-K, interpolation, Ilgaz National Park

\footnotetext{
": Bu çalışma; Ondokuz Mayıs Üniversitesi, Fen Bilimleri Enstitüsü tarafından kabul edilen birinci yazara ait "Ilgaz Milli Park Topraklarının Erozyon Duyarlılık Parametrelerinin Farklı Enterpolasyon Yöntemleriyle Konumsal Dağılımlarının Belirlenmesi” isimli Yüksek Lisans Tez çalışmasından üretilmiştir.
} 


\section{Giriş}

Yer küresinin en üst katmanını oluşturan toprak, insanlar tarafindan sadece bir üretim materyali olarak düşünülürken; bilim adamları tarafından içerisinde ve dışarısında canlılar alemi barındıran, yaşayan ve yaşatan, dinamik bir varlık olarak tanımlanmaktadır (Schaetzl ve Anderson, 2005; Dengiz ve ark., 2013; Tunçay ve Dengiz, 2016). Özellikle sanayi devriminden sonra insanlar, yeryüzü üzerinde yapmış oldukları negatif baskılar ve ekosistemler üzerinde görülen olumsuz yansımalar sonucu toprağın; artık tüm insanlık tarafindan karasal ekosistem hizmetlerinin yerine getirilmesinde önde gelen en önemli unsurlardan birisi ve verimli/üretken hale gelmesinin ve devamlılığının ne kadar yaşamsal öneme sahip olunduğunun farkına varmaktadırlar. Toprağın doğal oluşum sürecini değiştirmenin olanaksız olduğu gibi teknolojik imkânlarla, yapay üretilmesinin de mümkün olmadığı ve kaybedilmesi halinde yerine başka bir kaynağın kullanılamayacağı artık anlaşılmaya başlanılmıştır.

Karasal ekosistemin işlevselliğinde en önemli parçalarından birisi ve son derece etkili olan toprak; ekolojik, biyolojik, ekonomik ve kültürel fonksiyonlarıyla en önemli doğal ihtiyaçlardan birisidir (Kanar ve Dengiz, 2015a ). Buna karşın, yanlış ve plansız kullanımı, bitki örtüsünün tahribi, yangınlar, aşırı otlatma gibi nedenlerle doğal işlevlerini kaybetmesi, bu alanlarda arazi bozulumunu ve çölleșme riskinin önemli oranda artmasına neden olmaktadır. Arazi bozulumu karmaşık ve dinamik bir süreç içerisinde devam etmekle birlikte, kısa zaman süreleri içerisinde izlenmesi ve sonuçlarının değerlendirilmesi oldukça zordur ve çoğunlukla kalıcı etkileri gözlenebilir olduğunda, belirlenebilmektedir. $\mathrm{Bu}$ nedenle, arazi bozulumu/çölleşme, gerek kompleks ve dinamik yapı içermesiyle gerekse de arazi üretkenliğinin azalması veya tamamen kaybolmasıyla sonuçlanan bir süreç olarak nitelendirilmektedir (Karagöz ve ark., 2017). Arazi bozulumunun en ileri şekli olarak algılanan çölleşme ise, iklimsel değişiklikler ile fiziksel, biyolojik, siyasal, sosyal, ekonomik ve kültürel etmenlerin ve aralarındaki karşılıklı etkileşimlerin sonucunda, özellikle kurak, yarı kurak, kurakçayarı nemli ve nemlice-yarı nemli alanlar ile kuraklık/nemlilik özellikleri ne olursa olsun oluşan arazi bozulması ve ekolojik üretkenliğin azalması süreci olarak belirtilmiştir (Türkeş, 2013).

Türkiye topraklarının; gerek toprakların taşınmasına gerekse de bu taşınım nedeniyle çölleşmeye son derece duyarlı bir yapı göstermektedir. Bunun nedeni başta sahip olduğu iklim, coğrafi konum, topografya ve toprak özellikleriyle yakından ilgisi bulunmaktadır (Eraslan ve ark., 2016). Dolaysıyla Türkiye'nin çok farklı ekolojilere sahip olması, özellikle toprakların erozyon oluşturucu güçlere karşı gösterdiği dayanım olarak da tanımlayabileceğimiz "erozyon duyarlılığı”, değişen ekolojik koşullar (yağış şiddeti, eğim diklikleri, toprak yapısındaki ve hidrolik özelliklerdeki değişimler vb.) altında farklılaşmaktadır.

Toprağın aşınabilirliği, toprak özellikleri ile arazi kullanım durumuna bağlı olarak değiştiği gibi yağışın erosivitesine göre de değişebilir (Kanar ve Dengiz, 2015b) Toprağın aşınmaya karşı direncini veya erozyona karşı hassasiyetini ortaya çıkarmak için, erozyona sebep olan parametreler ve toprak özelliklerinin arasındaki ilişkilerinin saptanması gerekmektedir. Bu nedenle, erozyon planlamaları yapılmadan toprak ve su kaynakları, hem niteliksel hem de niceliksel olarak lokal ve/veya havza ölçeğinde önceden incelenmelidir. Toprakların aşınma karşı duyarlılıklarının incelenmesinde birçok araştırmacı (Wallis ve Stewan, 1961; Balcı ve Özyuvac1, 1974; Sönmez, 1982; Karagöktaş ve Yakupoğlu, 2014; Kanar ve Dengiz, 2015b) tarafından erodibilite faktörü, suya dayanıklı agregat stabilitesi, erozyon oranı, strüktür stabilitesi, kil oranı, dispersiyon oranı gibi birçok duyarlılık indeksi geliştirilmiş ve araştırılmıştır. Özellikle de son yıllarda yapılan çalışmalarda arazi kullanım ve arazi örtüsü, arazinin coğrafi özellikleri gibi sayısal tematik haritalar ile noktasal verilerin coğrafi bilgi sistemleri (CBS) ve uzaktan algilama (UA) teknikleri ve jeoistatistik gibi programların kullanılması ile daha hızlı ve güvenilir sonuçlar elde edilebilmektedir.

Bu çalışmanın amacı; Türkiye'de Ilgaz Milli Park alanı içerisinde dağılım gösteren toprakların; Evrensel Toprak Kayıp Eşitliğinin alt bileşeni olan toprak aşınım faktörü (USLE-K), dispersiyon oranı (DO) ve kil oranı (KO) gibi bazı erozyon duyarlılık parametrelerinin belirlenmesi ve CBS yardımıyla farklı enterpolasyon yöntemleri kullanılarak konumsal dağılımlarının haritalanmasıdır. Ayrıca duyarlılık parametreleri karşılaştırılarak alan içerisinde riski yüksek olarak belirlenen alanlara yönelik çözüm önerileri de getirilmesi amaçlanmaktadır.

\section{Materyal ve Yöntem}

\subsection{Araştırma yerinin tanımı ve bazı coğrafik özellikleri}

Ilgaz Dağı Milli Park1; Türkiye'nin Karadeniz Bölgesi, Batı Karadeniz Bölgesi'nde, Kastamonu ve Çankırı illeri sınırları içerisinde yer almaktadır. Alan 558759- 4548060 doğu boylamları ile 563823- 4544347 (UTM, Zone 36, m) kuzey 
enlemleri arasında bulunmaktadır (Şekil 1). Çalışma alanının yaklaşık 778.93 hektarı Kastamonu, 337.75 hektarı da Çankırı il sınırları içerisinde olup, toplam 1117.54 hektardan oluşmaktadır. Topografik yapısı, zengin orman ve bitki örtüsü, yüksek yaban hayatı potansiyeli, eşsiz manzara güzellikleri, zengin rekreasyon kaynakları, kış turizmi olanakları ve insan sağlığına faydalı atmosferi, alanın ana kaynak değerlerini oluşturmaktadır.

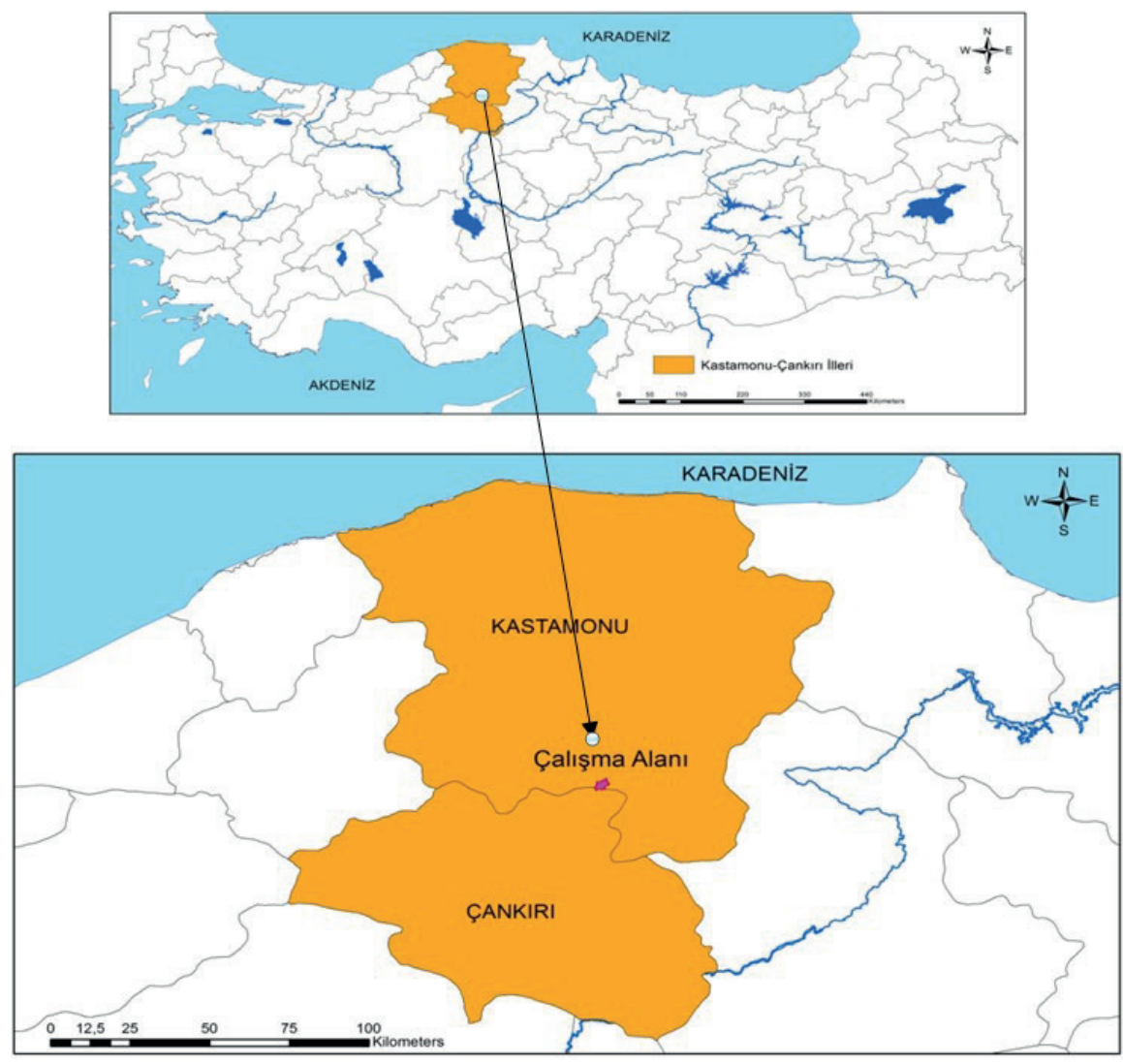

Şekil 1. Çalışma alanı lokasyon haritası

Milli Park sınırları içerisindeki; Kozançal Tepe (2070 m), Karakeçilik Tepe (1999 m), Baldıran Tepe (1931 m), Şadımanın Tepe $(1843$ m), Haydarın Sırtı ve Arpasekisi Sirtı önemli tepe ve yükseltilerdir. Milli Park dalgalı ve dağlık bir topografyaya sahip olup, deniz seviyesinden 1519 m ile $2072 \mathrm{~m}$ arasındaki yükseklikte yer almaktadır (Şekil 2).

Ilgaz Dağ1 Milli Park1 1/25000 ölçekli haritada F31c4 ve F31d3 paftaları içerisinde kalmaktadır. Milli Park'ın en alçak noktasına 1.500 metre ile parkın kuzeybatı köşesini sınırlayan Baldıran Dere'de ve en yüksek noktasına 2072 metre rakıma sahip olan parkın güneybatı köşesindeki Kozançal Tepe'de ulaşılmaktadır. Bu kadar küçük bir alan içerisinde bile 570 metre gibi önemli bir yükselti farkı ortaya çıkmaktadır. Dolayısıyla, alan içerisindeki eğim değerleri oldukça yüksektir. Bu durum sahadaki erozyonal etkiyi sağlayan rölyef enerjisini artırmakta, heyelanın gelişmesine önemli bir katkı sağlamakta risk oluşturabilmektedir.

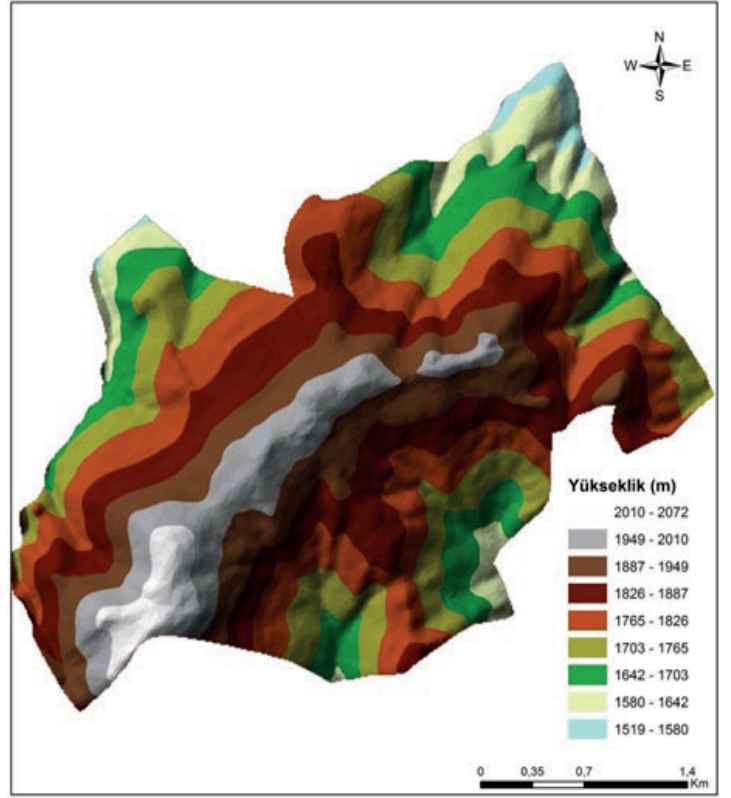

Şekil 2. Çalışma alanı yükselti haritası 
Çalışma alanı; üç farklı havzanın birleşme noktasının merkez olarak yer aldığı, havzaların beslenme alanlarının zirve kisımlarını kapsamaktadır. Bu havzalar; Karanlık Dere Havzası (I), Baldıran Dere Havzası (II) ve Gök Çay Havzası (III)'dır (Anonim, 2009). Çalışma alanı çok dik eğimli alanlara sahip olup (Şekil 3), baskın bak1 güneydoğu kesimleridir (Şekil 4).

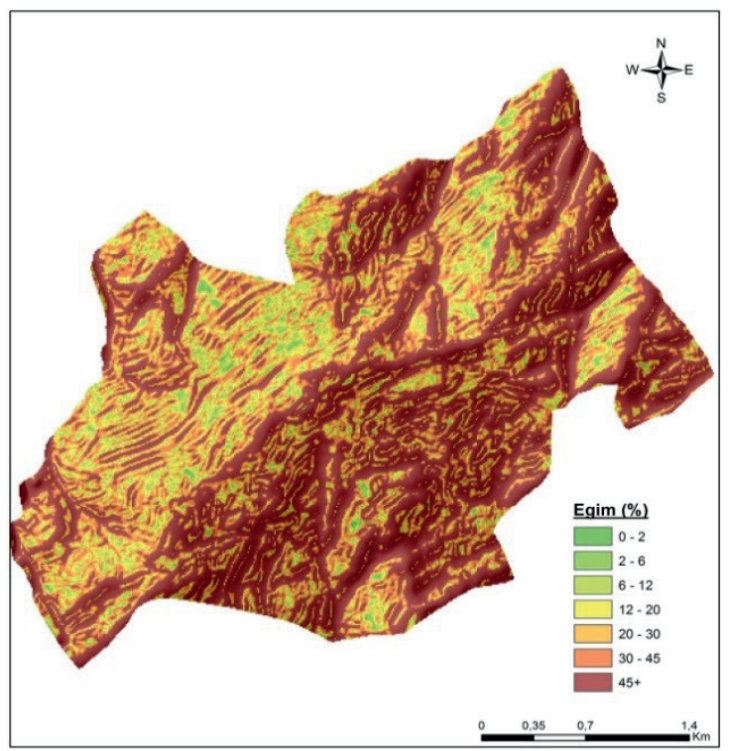

Şekil 3. Çalışma alanına ait eğim haritası

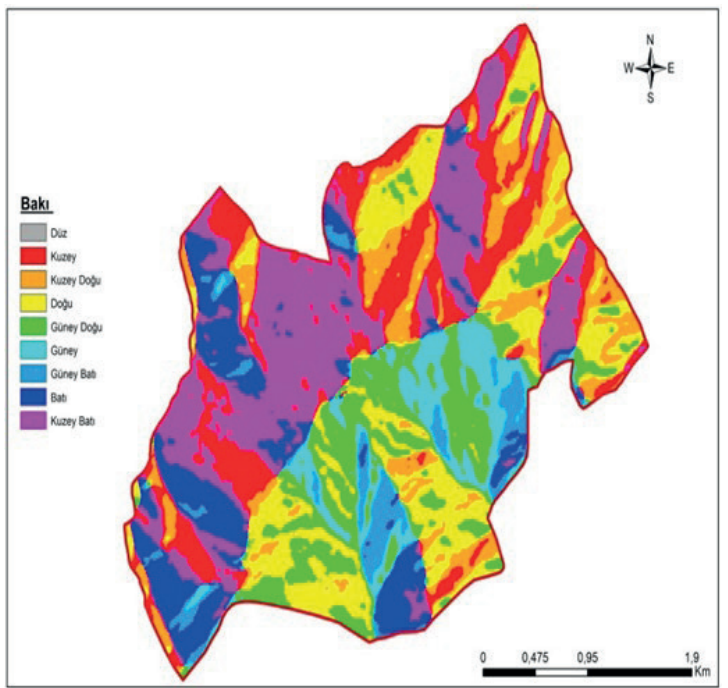

Şekil 4. Çalışma alanına ait bakı haritası

Çankırı ili Ilgaz ilçesi Meteoroloji İstasyonu uzun yillar (2009-2017) verileri dikkate alındığında; Thortwaite iklim sınıflamasına göre araştırma alanı B2 C2 s b2 (ikinci dereceden nemli, mikrotermal iklim, yazın orta derecede su noksan1, 2. dereceden denizsel özellik) iklim özelliği göstermektedir. Araştırma alanı yıllık ortalama yağış miktarı $680.5 \mathrm{~mm}$ ve sıcaklık ortalaması ise
$5.1{ }^{\circ} \mathrm{C}$ 'dir. Newhall similasyon modeline göre (Van Wambeke, 2000) çalışma alanı topraklarının toprak nemi Udic, alt sinıflamada ise Dry Tempudic olarak sınıflandırılmıştır. Araştırma alanının toprak sıcaklık rejimi ise; yıllık ortalama toprak sıcaklığ $0{ }^{\circ} \mathrm{C}$ ile $8{ }^{\circ} \mathrm{C}$ 'den az ve $50 \mathrm{~cm}$ 'deki yillık ortalama kış ayları toprak sıcaklığı ile yıllık ortalama yaz ayları toprak sıcaklığı arasındaki fark $6{ }^{\circ} \mathrm{C}$ 'den fazla olduğu için Cryic sıcaklık rejimi olarak bulunmuştur.

Çalışma alanı topraklarının büyük çoğunluğu pedolojik gelişimin henüz başlarında olan ve her hangi bir yüzey altı tanı horizonu bulunmayan; dolaysıyla genç olarak nitelendirilebilecek topraklar olup, toprak taksonomisi (Anonymous, 1999)'ne göre Entisol ordosuna dâhil edilmișlerdir. Topraklar eğimli ve sı ̆̆ derinliğe sahip topraklardır. $\mathrm{Bu}$ toprakların yüzey altında $50 \mathrm{~cm}$ derinlik içerisinde bir lithic kontak dışında her hangi bir tanı horizonu bulunmamaktadır. Topraklar; yamaç arazi üzerinde yer almaları nedeniyle orthent alt ordosuna, sicaklik rejiminden dolay1 cryorthent ve $50 \mathrm{~cm}$ derinliklerde ana kayaya ulaşılması nedeniyle de lithic cryorthent alt ordosunda sınıflandırılmışlardır.

Çalışma alanı içerisinde dağılım gösteren ana kaya çeşidi ise, kuzey doğu kesimlerinde genellikle kum taşı-çamur taşı-kireç taşı ardalanması görülürken, güneydoğu kısımlarında ise çoğunlukla filintler yer almaktadır. Ayrica alanın güneydoğusunda ince bir şerit halinde de çakıl taş1kumtaşı ve çamur taşı ardalanması yer almaktadır.

\subsection{Toprak duyarlılık parametrelerine ait yöntemler}

Dispersiyon oranı (DO): Toprağın süspansiyonda dispers edilmeden ölçülen ve yüzde (\%) ile ifade edilen silt+kil değerinin, mekanik analizde ölçülen silt+kil değerine (\%) oranlanmasıyla hesaplanmıştır (Lal, 1988).

Kil oranı (KO): Mekanik analizde ölçülen kum+silt değerinin (\%), kil değerine (\%) oranlanmasıyla hesaplanmıştır (Özdemir, 2002).

Erodibilite (USLE-K) faktörü: K faktörü, toprak aşınabilirlik nomogramı veya denklemi kullanılarak belirlenebilmektedir (Wischmeier ve Smith, 1978). Bu çalışmada, USLE-K için aşağıdaki Eşitlik 1 kullanılmıştır.

$$
\begin{aligned}
U S L E-K= & \frac{1}{100}\left\{2.1 \times 10^{-4} \times(12-O M) \times[S I \times(S A+S I)]^{1.14}\right. \\
& +2.5 \times(H I-3)+3.25 \times(S T-2)\}
\end{aligned}
$$

Eşitlikte K, toprağın erozyona duyarlılık faktörünü (t ha h ha ${ }^{-1} \mathrm{Mj}^{-1} \mathrm{~mm}^{-1}$ ); OM, organik 
madde miktarını (\%); SI, silt içeriğini; SA, kum içeriğini; Hİ, hidrolik iletkenlik değerini; ST, strüktür sınıfını ifade etmektedir. Bu eşitlikte, toprak OM miktarı \% 4'ten büyükse \% 4 olarak kabul edilmektedir (Renard ve ark., 1997). Farklı araştırmacıların, USLE-K değerleri yönünden sınıf aralık değerlendirmeleri Tablo 1'de verilmiștir. Eşitlik 1'den çıkan sonuçlara göre, Tablo 1'de belirtilen farklı araştırmacılara göre USLE-K sınıf değerleri belirlenmiştir.

Tablo 1. Farklı araştırmacılara göre USLE-K sınıf değerleri

\begin{tabular}{|c|c|c|c|c|c|c|}
\hline \multirow[t]{2}{*}{ Tanım } & \multicolumn{2}{|c|}{$\begin{array}{c}\text { Özdemir (2002), } \\
\text { Cebel ve ark. (2013) }\end{array}$} & \multicolumn{2}{|c|}{$\begin{array}{l}\text { İlay ve Kavdır (2018), } \\
\text { Dangler ve ark. (1976) }\end{array}$} & \multicolumn{2}{|c|}{ Pauwels ve ark. (1980) } \\
\hline & Sinif & Değer & Sinif & Değer & Sinif & Değer \\
\hline Çok az aşınabilir topraklar & 1 & $0.00-0.05$ & Çok düşük & $0-0.10$ & Düşük-çok düşük & $0-0.25$ \\
\hline Az aşınabilir topraklar & 2 & $0.05-0.10$ & Düşük & $0.10-0.20$ & Orta & $0.25-0.35$ \\
\hline Orta derecede aşınabilir topraklar & 3 & $0.10-0.20$ & Orta & $0.20-0.30$ & Yüksek & $0.35-0.45$ \\
\hline Fazla aşınabilir topraklar & 4 & $0.20-0.40$ & Orta-yüksek & $0.30-0.40$ & & \multirow{3}{*}{$0.45+$} \\
\hline \multirow{2}{*}{ Çok fazla aşınabilir topraklar } & \multirow{2}{*}{5} & \multirow{2}{*}{$0.40-0.60$} & Yüksek & $0.040-0.50$ & \multirow[t]{2}{*}{ Çok yüksek } & \\
\hline & & & Çok yüksek & $0.50+$ & & \\
\hline
\end{tabular}

2.3. Toprak örneklemesi ve toprak analiz yöntemleri

Milli Park sınırları içerisinde, 0-20 cm derinlikten toplam 151 adet toprak örneklemesi yapılmıştır (Şekil 5). Alınan toprak örnekleri laboratuvar ortamında kurutulduktan sonra, tahta tokmaklarla dövülerek $2 \mathrm{~mm}$ 'lik çelik elekten geçirilmiş ve analizlere hazır hale getirilmiştir.

Toprak örneklerinin tekstür analizi, hidrometre yöntemi kullanılarak (Bouyoucos, 1951); hidrolik iletkenlik (HI) değerleri, su seviyesinin sabit olduğu hidrolik geçirgen setler yardımıyla (Klute ve Dirksen, 1986); hacim ağırlığı (HA), $100 \mathrm{~cm}^{3}$ hacmindeki çelik silindirler yardımıyla alınan yapısı bozulmamış toprak örneklerinin $105^{\circ} \mathrm{C}$ sicaklıkta etüvde kurutularak hesaplamak suretiyle (Blake ve Hartge, 1986); organik madde, WalkleyBlack yöntemiyle (Kacar, 1994); pH, 1:2.5 oranında hazırlanan toprak-su süspansiyonunda cam elektrotlu pH metre ile ölçülmek suretiyle (Anonymous, 1992); elektriksel iletkenlik (EC) değerleri, 1:2.5 oranında hazırlanan toprak-su süspansiyonunda elektriksel kondaktivite aleti ile (Richards, 1954); kireç miktarı, Scheibler Kalsimetresi ile (Kacar, 1994); toplam azot (N), mikro Kjeldahl (Bremner ve Mulvaney, 1982) yöntemiyle; yarayışlı potasyum $(\mathrm{K})$, amonyum asetat (NH4OAc) ile ekstrakte edilen potasyumun analiz edilmesi ile (Anonymous, 1992) ve yarayışl fosfor (P), Olsen metodu (Olsen ve ark., 1954) kullanılarak belirlenmiştir.

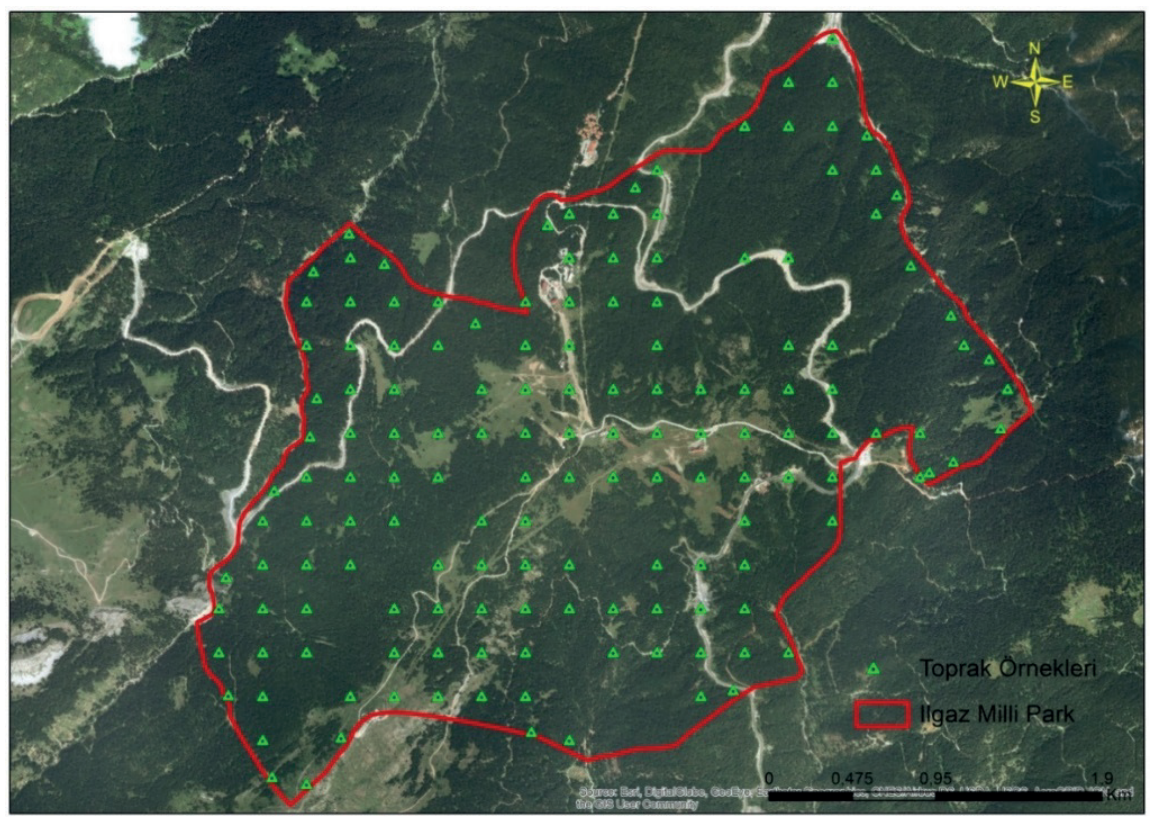

Şekil 5. Çalışma alanı içerisinde toprak örnekleme deseni 


\subsection{Enterpolasyon yöntemleri}

Toprak analizlerinden elde edilen noktasal verilerin alansal dağılımını belirlemek için enterpolasyon yöntemleri kullanılmaktadır. Bu çalışma kapsamında deterministik yöntemlerden Radyal Tabanlı Fonksiyon (RBF), Ters Mesafe Ağırlıklı Enterpolasyon (IDW) yöntemi; stokastik yöntemlerden Ordinary Kriging (OK), Basit Kriging (SK) ve Universal Kriging (UK) yöntemleri karşılaştırılmıştır. Çalışmada, IDW yönteminde 1., 2., ve 3. kuvvet (IDW-1, IDW-2 ve IDW-3), RBF yönteminde Düzeltilmiş Spline [Completely Regularized Spline (CRS)] modeli, kriging metotlarında ise küresel (Spherical), Üssel (Exponatial) ve Gaussian modeller kullanılmıştır.

Ölçülen değerler ve enterpolasyonlar sonucu tahmin edilen değerler arasındaki ilişkiyi sorgulayabilmek, ölçülen değerlere en yakın sonucu veren, başka bir ifade ile yöntemler arasından en uygun olanının seçilmesinde literatürde farklı karşılaştırma yöntemlerinin dikkate alındığ 1 görülmektedir. $\mathrm{Bu}$ çalışmada, modellerin karşılaştırmalarının yapılması ve en uygun modelin seçilebilmesi için en çok kullanılan Ortalama Hata Kareleri Toplamının Karekökü (RMSE) yöntemi kullanılmıştır. RMSE yönteminde, tahmin edilen ve gözlenen değerler arasındaki korelasyon değerleri kullanılmaktadır. Hazırlanan haritalarda, tahminin ortalama hatası sifir (0)'a yakın ve tahminin standardize ortalama hatalar karekökü ise 1'e ne kadar yakın ise haritanın aynı oranda doğru olduğu anlaşılmaktadır (Johnston ve ark., 2001). Diğer bir ifade ile en düşük RMSE değerini veren yöntem, en uygun yöntem olarak değerlendirilmiştir. Buna göre, RMSE değerlerinin hesaplanmasında Eşitlik 2 kullanılmıştır (Ding, 2011).

$$
R M S E=\sqrt{\frac{\sum\left(Z_{i *}-Z_{i}\right)^{2}}{n}}
$$

Eşitlikte; $Z_{i}$, tahmin edilen değeri; $Z_{i}{ }^{*}$, ölçülen değeri; $n$, örnek sayısını ifade etmektedir.

Farklı istatistik testler yapmak için "normal dağılımdan" uzak dağılımlar sergileyen veri setlerinde normal dağılıma yaklaştırmak amacıyla kil oranı değerleri için logaritmik dönüşüm yapılmıştır. Toprak özelliklerinin tanımsal istatistik özelliklerini ortaya koymak amacıyla, tanımlayıcı istatistikleri (mimimum, maksimum, ortalama, standart sapma, çarpıklık, basıklı, varyasyon katsayısı vb.) hesaplanarak, normal dağılıma uygunlukları Kolmogorov-Smirnov testi SPSS (Karaatl1, 2010) ile kontrol edilmiştir.

\section{Bulgular ve Tartışma}

\section{1. Çalışma alanı topraklarının bazı fiziksel ve kimyasal özellikleri ve tanımlayıcı istatistikleri}

Toprakların aşınmaya karşı duyarlılıkları, sahip oldukları aşınmayı etkileyen fiziksel ve kimyasal özelliklerindeki farklılıklarından ileri gelmektedir. Nitekim birçok çalışmalarda, aşınımı etkileyen en önemli toprak özellikleri olarak; toprağın bünyesi, strüktürü, hidrolik iletkenlik değeri ve organik madde kapsamı olduğu (Cebel ve ark., 2013; Prosdocimi ve ark., 2016; Yakupoğlu ve ark., 2017) rapor edilmiştir.

Araştırma sahasında toplam 151 adet toprak örneği alınmıştır. Bu örneklerde 15 adet farklı fiziksel ve kimyasal özellik incelenmiştir. Normal dağılım simetrik bir dağılımdır. Normal dağılımda simetrikliğin bozulma derecesine çarpıklık (skewness) denir. Dağılış sağa uzun kuyruklu ise sağa (pozitif) çarpık, sola uzun kuyruklu ise sola (negatif) çarpık olarak adlandırılır. Normal dağılım eğrisinin sivrilik veya yuvarlaklık derecesine basıklık (kurtosis) denir (Yıldız ve ark., 1999). Toprakların tanımsal istatistiklerine yönelik sonuçlar Tablo 2'de verilmiştir. Tablo 2'den görüleceği üzere, toprak özelliklerinden $\mathrm{pH}$ ve kumun çarpıklık katsayıları normal dağılımdan uzak negatif (sola) çarpıklığa sahiptirler. Wilding (1985) ve Mallants ve ark. (1996), toprak özelliklerindeki değişimlerin açıklanmasında önemli bir gösterge olarak kabul edilen değişkenlik katsayısını, aldığ 1 değerlere göre düşük $(<\% 15)$, orta $\left(\begin{array}{ll}\% & 15-35)\end{array}\right)$ ve yüksek $(>\%$ 35) olarak sınıflandırmaktadır. Buna göre toprakların $\mathrm{pH}$ ve HA değerleri düşük değişkenlikte iken, silt ve kum değerleri orta değişkenliktedir. Diğer tüm toprak özelliklerinin ise yüksek değişkenliğe sahip olduğu görülmüştür (Tablo 2). Özyazıcı ve ark. (2016) tarafından yapılan araştırma sonucunda da benzer bulgular elde edilmiş, $\mathrm{pH}\left(\begin{array}{l}\% \\ \%\end{array}\right.$ (\% 28.03) dışındaki incelenen bütün fizikokimyasal toprak özelliklerinin yüksek değişkenliğe sahip olduğu, en fazla değişkenlik gösteren toprak özelliğinin kireç $\left(\begin{array}{lll}\% & 173.21\end{array}\right)$ olduğu rapor edilmiştir.

Toprakların toplam N değerlerinin \% 0.02\% $\quad 0.72$ arasında değiştiği belirlenmiştir. $\mathrm{Bu}$ değerlere göre toprakların $\mathrm{N}$ içerikleri, az-çok fazla düzeyleri arasında geniş bir sınıfta dağılım göstermektedir. Toprakların alınabilir $\mathrm{P}$ değerleri ise $0.10-13.0 \mathrm{~kg} \mathrm{P}_{2} \mathrm{O}_{5} \mathrm{da}^{-1}$ arasında olup, yüksek değişkenliğe sahip olmuştur. Toprakların $\mathrm{K}$ 
kapsamları ise 8-163 $\mathrm{kg} \mathrm{K}_{2} \mathrm{O} \mathrm{da}^{-1}$ arasında değişen değerler göstermiş olup, ortalama değeri $58 \mathrm{~kg} \mathrm{~K}_{2} \mathrm{O}$ $\mathrm{da}^{-1}$ olarak belirlenmiştir (Tablo 2).

Toprakların organik madde miktarının \% 0.37 ile \% 21. 42 arasında değişen değerler gösterdiği tespit edilmiştir (Tablo 2). Ülgen ve Yurtsever (1995) tarafından bildirilen sinıflandırmaya göre toprakların azdan çok fazla sınıfına kadar değişen miktarda organik madde içerdiği belirlenmiştir.

Araştırma alanından alınan toprak örneklerinin kireç kapsamlarının, kimyasal özellikler içerisinde en fazla değişkenlik katsayısına sahip olduğu görülmüş; toprakların kireç içeriklerinin \% 0.8 \% 44.1 arasında değiştiği belirlenmiştir (Tablo 2). Ülgen ve Yurtsever (1995) tarafından bildirilen sınıflandırmaya göre, topraklar kireç içerikleri yönünden az kireçli ile çok fazla kireçli arasında dağılım gösteren sınıflandırmaya sahip olmuştur.

Araştırma topraklarının EC değerleri 0.047$0.118 \mathrm{dS} \mathrm{m}^{-1}$ arasında değişmekte olup (Tablo 2), incelenen toprakların tuzluluk yönünden bir problemi olmadığını söylemek mümkündür.

Toprakların pH değerleri ise 4.09-7.38 arasında değişmektedir (Tablo 2). Ülgen ve Yurtsever (1995) tarafından bildirilen sınıflandırma esas alındığında, toprak örneklerinin kuvvetli asit ile nötr arasında değişen pH sınıflarına sahip olduğu görülmüştür.

Toprakların fiziksel özelliklerindeki değişime bakıldığında; araştırma sahası topraklarının, kum miktar1 \% 14.59-79.40, kil miktar1 \% 4.08-45.45 ve silt miktarı ise \% 8.69-46.38 arasında değiştiği belirlenmiştir (Tablo 2). Toprakların bünyesel olarak büyük çoğunluğu orta bünyeli topraklar (\% 58.94) oluştururken, kaba bünyeli toprakların oranı \% 37.75 olmuş; ağır bünyeli topraklar ise çalışma alanı içerisinde çok az miktarda dağılım göstermiştir. Topraklar; kil (C), killi tın (CL), tın (L), tınlı kum (LS), kumlu kil tın (SCL), siltli tın (SiL) ve kumlu tın (SL) sinıflarında analiz edilmiştir.

Toprakların HA değerleri $0.99-1.59 \mathrm{gr} \mathrm{cm}^{-3}$ arasında değişmektedir (Tablo 2). Buna göre araştırma sahası HA farklı tekstürel özelliklere bağlı farklı değerler gösterdiği görülmüştür. Toprakta hidrolik geçirgenlik durumu ise su akış hızı birim zamanda toprağın birim kesit alandan birim yük farkı altında geçen su miktarıdır ve birimi, uzunluğun zamana oranı olarak ifade edilir (Özdemir, 1998). Araştırma topraklarının ortalama Hİ değeri $3.59 \mathrm{~cm} \mathrm{~h}^{-1}$ olup; Hİ, 0.18-14.93 $\mathrm{cm} \mathrm{h}^{-1}$ arasında değişim göstermiştir (Tablo 2). Bu sonuçlar, toprakların hidrolik iletkenliklerinin orta yavaş ile orta değerler gösterdiğini ifade etmektedir.

Toprakların erozyon duyarlılık parametrelerindeki değişimler incelendiğinde; DO, $\mathrm{KO}$ ve USLE-K değerlerinin sirasıyla \% 8.73$\%$ 70.64, \% 1.20-23.49 ve 0.01-0.95 tha h ha-1 $\mathrm{Mj}$ $\mathrm{mm}^{-1}$ arasında değiştiği tespit edilmiştir (Tablo 2). Dispersiyon oranı ne kadar düşük olursa toprak aşınmaya karşı o kadar dirençli olmaktadır. Çalışma alanı topraklarının ortalama DO değeri 33.08 ile; Bryan (1968)'a göre oldukça yüksek, Elges (1985)'e göre ise orta düzeyde dispers olma özelliği taşımaktadır. USLE-K değerlerine göre, sahanın aşınım sınıfları çok az aşınabilir ile çok fazla aşınabilir sınıfları arasında dağılış göstermektedir.

Tablo 2. Toprakların fiziksel ve kimyasal özelliklerine ait tanımlayıcı istatistikleri

\begin{tabular}{|c|c|c|c|c|c|c|c|c|c|}
\hline \multirow{2}{*}{$\begin{array}{l}\text { Toprak } \\
\text { parametreleri }\end{array}$} & \multicolumn{9}{|c|}{ İstatistiki parametreler } \\
\hline & Ort. & Min. & Mak. & Med. & SS & $\mathrm{D}$ & Ç & B & $\mathrm{CV}$ \\
\hline $\mathrm{N}, \%$ & 0.22 & 0.02 & 0.72 & 0.21 & 0.1 & 0.02 & 1.19 & 1.46 & 60.70 \\
\hline $\mathrm{P}, \mathrm{kg} \mathrm{P}_{2} \mathrm{O}_{5} \mathrm{da}^{-1}$ & 3.51 & 0.10 & 13.00 & 3.10 & 2.03 & 4.1 & 1.18 & 2.59 & 57.96 \\
\hline $\mathrm{K}, \mathrm{kg} \mathrm{K}_{2} \mathrm{O} \mathrm{da}^{-1}$ & 58.19 & 8.00 & 163.00 & 50.00 & 34.0 & 1160.5 & 0.75 & -0.05 & 58.53 \\
\hline $\mathrm{OM}, \%$ & 6.04 & 0.37 & 21.42 & 5.88 & 3.3 & 11.2 & 1.06 & 2.32 & 55.54 \\
\hline $\mathrm{CaCO}_{3}, \%$ & 2.84 & 0.80 & 44.10 & 1.10 & 6.0 & 36.8 & 4.52 & 22.51 & 212.93 \\
\hline $\mathrm{EC}, \mu \mathrm{S} \mathrm{m}^{-1}$ & 275.74 & 47.46 & 1185.0 & 227.1 & 183.7 & 33767.8 & 1.60 & 3.71 & 66.64 \\
\hline $\mathrm{pH}$ & 5.72 & 4.09 & 7.38 & 5.66 & 0.7 & 0.6 & -0.08 & -0.75 & 13.53 \\
\hline Kil, \% & 20.62 & 4.08 & 45.45 & 19.73 & 8.5 & 73.8 & 0.35 & -0.09 & 41.68 \\
\hline Silt, \% & 25.76 & 8.69 & 46.38 & 25.18 & 6.0 & 36.5 & 0.43 & 0.33 & 23.45 \\
\hline Kum, \% & 53.33 & 14.59 & 79.40 & 52.14 & 12.2 & 150.8 & -0.14 & -0.34 & 23.02 \\
\hline $\mathrm{HA}, \mathrm{gr} \mathrm{cm}^{-3}$ & 1.27 & 0.99 & 1.59 & 1.26 & 0.1 & 0.02 & 0.13 & -0.98 & 11.27 \\
\hline $\mathrm{HI}, \mathrm{cm} \mathrm{h}^{-1}$ & 3.59 & 0.18 & 14.93 & 2.72 & 2.8 & 8.3 & 1.54 & 2.69 & 80.34 \\
\hline DO & 33.08 & 8.73 & 70.64 & 33.56 & 13.2 & 175.9 & 0.24 & -0.25 & 40.09 \\
\hline $\mathrm{KO}$ & 5.14 & 1.20 & 23.49 & 4.07 & 3.9 & 15.4 & 2.62 & 8.31 & 76.34 \\
\hline $\begin{array}{l}\text { USLE-K, } \\
\text { t ha h ha-1 } \mathrm{Mj} \mathrm{mm}^{-1}\end{array}$ & 0.36 & 0.00 & 0.95 & 0.36 & 0.2 & 0.04 & 0.25 & -0.33 & 57.31 \\
\hline
\end{tabular}

Ort.: Ortalama, Min.: Minimum, Mak.: Maksimum, Med.: Medyan, SS: Standart Sapma, D: Değișim, C: Çarpıklık, B: Basıklık, CV: Varyasyon katsayısı, KO: Kil oranı, DO: Dispersiyon oranı, HA: Hacim ağırlı̆̆ı, HI: Hidrolik iletkenlik, OM: Organik madde 
3.2. Erozyon duyarlılı parametrelerinin enterpolasyon modelleri ve dağılım haritaları

Enterpolasyon modeller kullanılarak herhangi bir toprak özelliğinin konumsal değişim deseninin belirlenmesi, incelenen toprak özelliğinin çalışma sahası içerisinde herhangi bir noktasındaki değerini, en az hata ile tahmin etmeye imkân sağlar. Böylece, toprak özelliklerinin enterpolasyon analizi sonucu elde edilen değişim haritaları, inceleme alanı için arazi yönetimi ile ilgili en uygun planlama ve yönetim kararların alınması ve uygulanmasına olanak verir (Öztaş, 1996; Özyazıcı ve ark., 2015;
Gülser ve ark., 2016). Ele alınan toprak parametrelerinin dağılım haritalarını oluşturmak amaciyla 15 adet enterpolasyon modellerine ait RMSE değerleri elde edilmiş ve Tablo 3'te verilmiştir. Buna göre DO için en düşük RMSE değerine sahip (11.6548) Basit Kriging'in Küresel modeli dağılım haritası oluşturma yönünden en uygun model olarak belirlenirken; 0.17346 RMSE değeri ile USLE-K için IDW'nin 2. Modeli, KO için ise 3.85742 RMSE değeri ile yine Basit Kriging'in Gaussian modeli uygun olduğu saptanmıştır.

Tablo 3. Toprak parametrelerine ait uygulanan enterpolasyon modelleri ve RMSE değerleri

\begin{tabular}{|c|c|c|c|c|c|}
\hline \multirow{2}{*}{ Enterpolasyon modeller } & \multirow{2}{*}{\multicolumn{2}{|c|}{ Semivariogram modeller }} & \multicolumn{3}{|c|}{ Erozyon duyarl111k parametreleri } \\
\hline & & & DO & USLE-K & $\mathrm{KO}$ \\
\hline \multirow{3}{*}{ IDW } & IDW-1 & & 11.7103 & 0.17525 & 3.94895 \\
\hline & IDW-2 & & 11.7191 & 0.17346 & 4.02236 \\
\hline & IDW-3 & & 11.8974 & 0.17502 & 4.13213 \\
\hline \multirow{3}{*}{ RBF } & TPS & & 13.5491 & 0.19072 & 4.82500 \\
\hline & CRS & & 11.7414 & 0.17349 & 4.01209 \\
\hline & SWT & & 11.7257 & 0.17348 & 3.99342 \\
\hline \multirow{9}{*}{ Kriging } & \multirow{3}{*}{ Doğal } & Gaussian & 11.7492 & 0.17423 & 3.89443 \\
\hline & & Üssel & 11.8517 & 0.17439 & 3.93465 \\
\hline & & Küresel & 11.7720 & 0.17484 & 3.91040 \\
\hline & \multirow{3}{*}{ Basit } & Gaussian & 11.6945 & 0.17588 & 3.85742 \\
\hline & & Üssel & 11.8645 & 0.17565 & 3.88850 \\
\hline & & Küresel & 11.6548 & 0.17446 & 3.86284 \\
\hline & \multirow{3}{*}{ Evrensel } & Gaussian & 11.7492 & 0.17423 & 3.89443 \\
\hline & & Üssel & 11.8517 & 0.17439 & 3.93465 \\
\hline & & Küresel & 11.7721 & 0.17484 & 3.91040 \\
\hline
\end{tabular}

TPS: Thin Plate Splin, CRS: Completely Regularized Spline, SWT: Spline With Tension, DO: Dispersiyon oranı, KO: Kil oranı

Toprak ve su korumaya yönelik planlamalarda toprağın strüktürel devamlılığının değiştirilmesine karşı toprağın göstereceği direncin ve erozyona uğrama eğiliminin bilinmesine gerek duyulmaktadır (Sönmez ve Özdemir, 1988). Buna yönelik olarak birçok erozyon duyarlılık indisleri geliştirilmiştir. Bu erozyon duyarlılık indislerinden birisi de dispersiyon oranıdır. Bryan (1968), DO değeri \% 15'ten küçük olan topraklar erozyona karşı dayanıklıdırlar şeklinde belirtmiştir. Çalışma alanı içerisinden alınan 151 toprak örneğinde \% 12.6's1 DO bakımından \% 15 değerin altında, yani erozyona karşı dayanıklı olarak belirlenirken; alanın büyük kısmı ise DO bakımından, erozyona karşı duyarlı olduğu belirlenmiştir. Buna ek olarak, Elges (1985) tarafindan bildirilen DO siniflaması (\% DO $>\%$ 50, aşır1 dispers; \% 30-\% 50, orta dispers; \% 15-\% 30, az dispers; \% $\mathrm{DO}<\% \quad 15$, dispers değil) dikkate alındığında ise; çalışma alanı topraklarının \% 12.6's1 "dispers değil" sınıfında yer alırken, \% 58.3'ü ise aşırı ve orta dispers, \% 29.1' $\mathrm{i}$ ise az dispers sınıfında yer almaktadır.

Dispersiyon oranı ve kil oranı için dağılım haritalarının oluşturulmasında değerlerin sıklık dağılımı ve istatistik bilgiler göz önünde bulundurularak yapılan çalışmalar sonrasında, dağılımların alan içerisindeki eğilimlerinin belirlenmesi amacıyla CBS ortamında doğal kırınım (Natural Breaks Jenks) yöntemi ile 10 sınıfta gösterilmesi uygun olarak değerlendirilmiştir. $\mathrm{Bu}$ yöntem, verilerin eşit dağılmadığı, değerler arası büyük farklılıkların olduğu ve sınıflar arası farklılıkların belirgin olarak sunulma ihtiyacı olduğu durumlarda kullanılmaktadır.

Dispersiyon oranı dağılım haritası Şekil 6'da verilmiştir. Şekil 6 incelendiğinde özellikle çalışma alanının güney ve güneybatısına doğru ilerledikçe DO değerinin arttığ1 ve \% 50’ler seviyesini aştı̆̆ 1 görülmektedir. Erol ve ark. (2009) tarafindan Isparta-Darıderesi Havzası topraklarında erozyona duyarlılığın arazi kullanım şekillerine bağlı değişimine yönelik yürütülen çalışmada, dispersiyon oranının orman, tarım ve mera topraklarının tamamında \% 15 'ten büyük çıkmış ve topraklar erozyona dayanıksız bulunmuş; bir diğer ifadeyle tüm arazi kullanım topraklarında erozyona duyarlılığın yüksek olduğu belirtilmiştir. Ayrıca 
araştırmacılar, çalışma alanı topraklarının erozyona duyarlılığının orman topraklarında daha az olduğunu, ancak bu oranların sabit değerleri aştığını bildirmiş̧lerdir.

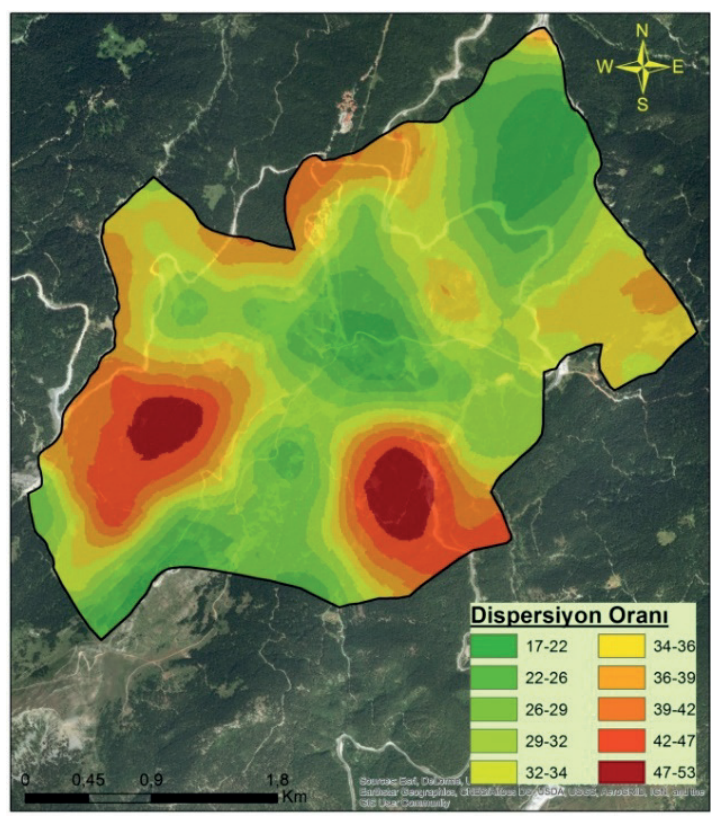

Şekil 6. Çalışma alanına ait DO dağılım haritası

Erozyona duyarlılık parametrelerinden bir diğeri de toprakların kil oranı olup, bu oran için sınır değer bulunmamaktadır. Genel olarak; KO küçüldükçe, toprakların erozyona karşı dayanıklılık derecesi de artmaktadır (Irmak, 1968; Gülçur, 1974; Sönmez, 1994). Dispersiyon oranında olduğu gibi, KO değerlerinin çalışma alanı içerisinde dağılım haritasını oluşturmak ve artan/azalan eğilim yönlerini görebilmek amacıyla doğal kırınım (Natural Breaks Jenks) yöntemi ile 10 sinıfa ayrılmıştır. Kil oranı dağılım haritası Şekil 7'de verilmiştir. Çalışma alanı topraklarının KO değerleri 1.20 ile 23.49 arasında değişmektedir. Şekil 7 incelendiğinde çalışma alanının büyük bir bölümünü oluşturan orta kesimleri ile güney güneydoğu kesimlerine doğru KO oranı değerleri azalma, yani toprakların erozyona karşı dayanıklılık derecesi artmasına karşın, kuzey ve kuzeybatıya doğru az bir alanda KO değerinde artış olduğu görülmektedir. Erol ve ark. (2009) IspartaDarıderesi Havzası'ndaki arazilerin KO değerlerini incelemişler ve orman, tarım ve mera topraklarında 5.22, 7.31 ve 10.53 arasında değiştiğini belirlemişlerdir. Kil oranı değerleri; orman ve tarım topraklarında istatistiki anlamda benzer olduklarını belirlerken, mera topraklarında daha yüksek ve orman ve tarım topraklarından farklı bulmuşlardır. Kil oranı değeri, mera topraklarında orman ve tarım topraklarına göre daha yüksek ve istatistiki olarak ta anlamlı olarak bulunmuştur. $\mathrm{Bu}$ durum, kil oranının saptanmasında organik madde miktarının dikkate alınmamasından kaynaklandığını belirtmişlerdir. Nitekim orman, tarım ve mera topraklarının organik madde miktarlarına bakıldığında orman topraklarının organik madde miktarı bakımından mera topraklarından daha yüksek olduğu tespit edilmişlerdir.

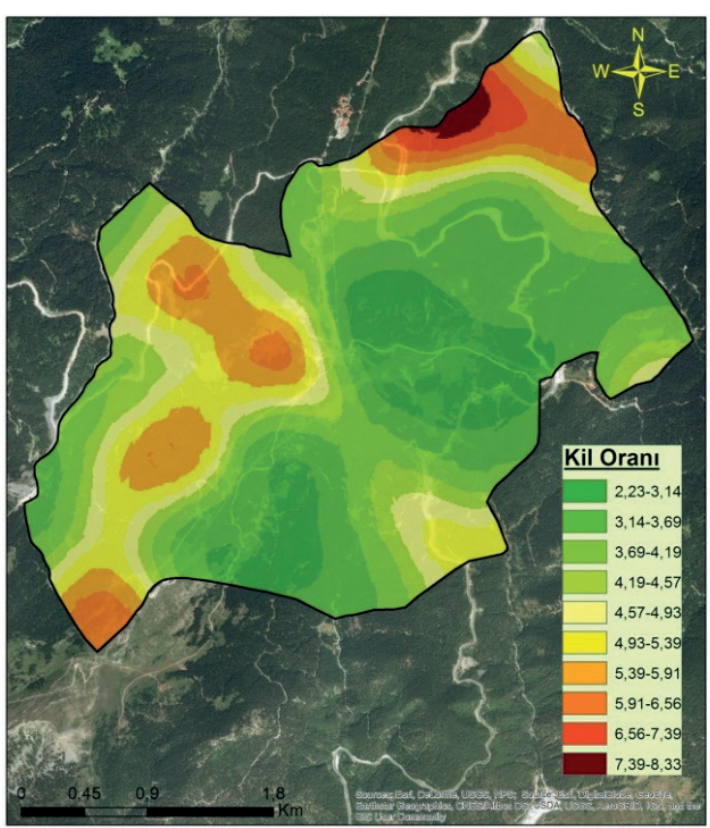

Şekil 7. Çalışma alanına ait KO dağılım haritası

Toprak erodibilite faktörü genel anlamda USLE modelinde $\mathrm{K}$ faktörü olarak belirtilmektedir. Toprak erodibilitesi toprağın aşınmaya, sıçramaya, sürüklenmeye karşı doğasındaki dirençtir. Bu, toprak partiküllerinin arasındaki kohezif kuvvetlerle ilgilidir. Kohezif kuvvetler bitki örtüsü, toprak nem içeriği, toprak strüktürünün dayanıklılığına göre değişebilmektedir (İlay ve Kavdır, 2018). Farklı araştırmacılara göre USLE- K sinıf değerleri Tablo 4'te, her bir sinıflamaya göre oluşturulan dağılım haritaları ise Şekil 8'de verilmiştir. Pauwels ve ark. (1980)'na göre 4 sınıf içerisinde değerlendirilen USLE-K sınıfları dağılımına bakıldığında; düşük ve çok düşük sınıf alanın \% 24.7'sini oluştururken, alanın yarıdan fazlası yüksek ve çok yüksek sınıfa girmektedir. Özdemir (2002) ve Cebel ve ark. (2013)'na göre 5 sınıf içerisinde değerlendirilen USLE-K sınıfları dağılımına bakıldığında ise, toplam alanın \% 2.2'si (24.7 ha) çok az ve az aşınabilir topraklar sınıfında yer alırken, alanın büyük bir kısmı (\% 86.9) fazla ve çok fazla aşınabilir topraklar sınıfını oluşturmaktadır. Yalnız alanın \% 10.9'luk kısmı ise orta derecede aşınabilir topraklar oluşturmaktadır. Ayrıca, Dangler ve ark. (1976) ve İlay ve Kavdır (2018)'a göre de USLE-K değerleri 6 sınıf aralığında değerlendirilmekte olup, alanın \% 13.1'i 
Tablo 4. Farklı sınıflandırmalara göre elde edilen USLE-K sınıf değerleri

\begin{tabular}{|c|c|c|c|c|c|c|c|c|c|c|c|}
\hline \multicolumn{4}{|c|}{$\begin{array}{c}\text { Özdemir (2002), } \\
\text { Cebel ve ark. (2013) }\end{array}$} & \multicolumn{4}{|c|}{$\begin{array}{l}\text { Dangler ve ark. (1976), } \\
\text { İlay ve Kavdır (2018) }\end{array}$} & \multicolumn{4}{|c|}{ Pauwels ve ark. (1980) } \\
\hline & Sinif & $\begin{array}{l}\text { Alan } \\
\text { (ha) }\end{array}$ & $\%$ & & Sinif & $\begin{array}{l}\text { Alan } \\
\text { (ha) }\end{array}$ & $\%$ & & Sinif & $\begin{array}{c}\text { Alan } \\
\text { (ha) }\end{array}$ & $\%$ \\
\hline 1 & $\begin{array}{c}\text { Çok az } \\
\text { aşınabilir } \\
\text { topraklar }\end{array}$ & 6.61 & 0.59 & 1 & $\begin{array}{l}\text { Çok } \\
\text { düşük }\end{array}$ & 24.70 & 2.21 & 1 & $\begin{array}{l}\text { Düşük- } \\
\text { çok düşük }\end{array}$ & 276.31 & 24.72 \\
\hline 2 & $\begin{array}{l}\text { Az aşınabilir } \\
\text { topraklar }\end{array}$ & 18.09 & 1.61 & 2 & Düşük & 121.78 & 10.89 & 2 & Orta & 259.28 & 23.20 \\
\hline 3 & $\begin{array}{c}\text { Orta } \\
\text { derecede } \\
\text { aşınabilir } \\
\text { topraklar }\end{array}$ & 121.78 & 10.89 & 3 & Orta & 256.23 & 22.92 & 3 & Yüksek & 284.14 & 25.42 \\
\hline 4 & $\begin{array}{c}\text { Fazla } \\
\text { aşınabilir } \\
\text { topraklar }\end{array}$ & 538.56 & 48.19 & 4 & $\begin{array}{l}\text { Orta- } \\
\text { yüksek }\end{array}$ & 282.33 & 25.26 & 4 & $\begin{array}{l}\text { Çok } \\
\text { yüksek }\end{array}$ & 297.81 & 26.64 \\
\hline 5 & $\begin{array}{l}\text { Çok fazla } \\
\text { aşınabilir } \\
\text { topraklar }\end{array}$ & 432.5 & 38.70 & 5 & Yüksek & 243.28 & 21.76 & Top & lam & 1117.5 & 100 \\
\hline & Toplam & 1117.5 & 100 & 6 & $\begin{array}{l}\text { Çok } \\
\text { yüksek }\end{array}$ & 189.22 & 16.93 & & & & \\
\hline
\end{tabular}
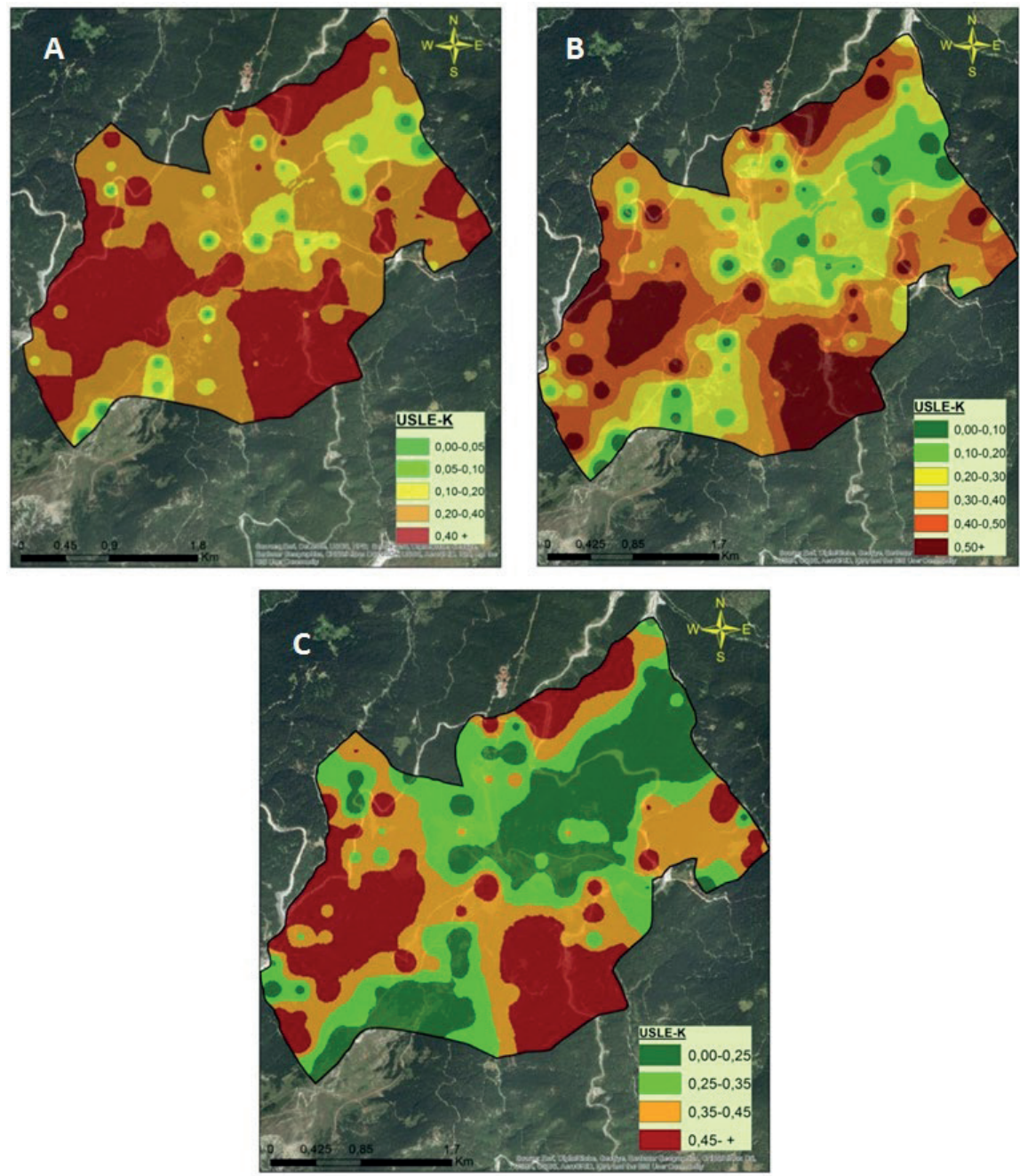

Şekil 8. Çalışma alanına ait USLE-K dağılım haritaları [A: Özdemir (2002) ve Cebel ve ark. (2013) sınıflamasına göre, B: Dangler ve ark. (1976) ve İlay ve Kavdır (2018) sınıflamasına göre, C: Pauwels ve ark. (1980) ve İlay ve Kavdır (2018)] 
çok düşük ve düşük değerler arasında iken, \% 63.95'i ise orta yüksek, yüksek ve çok yüksek sınıflar arasında oldukları belirlenmiştir. Her üç değerlendirme sınıfları birlikte ele alındığında, çalışma alanının yarıdan fazlası çok fazla veya çok yüksek aşınabilir özellikte olduğu görülmektedir (Şekil 8).

Erol ve ark (2009), Isparta sınırları içerisinde yer alan Darıderesi Havzası'nda dağılım gösteren topraklar üzerinde yürüttükleri araştırmada, USLEK faktörü bakımından Darıderesi Havzası'ndaki orman, tarım ve mera kullanımı altındaki tüm toprakların fazla derecede aşınabilir topraklar sınıfına girdiğini; arazi kullanımlar arasındaki farkın istatistiki anlamda önemli olmadığını belirlemelerine karşın, aşınım derecesinin şiddeti orman, tarım ve mera topraklarına doğru bir artış eğilimi gösterdiğini rapor etmişlerdir. Benzer şekilde Belasire ve ark. (2017) USLE-K faktörünü kullanarak, Fas'ın Oued El Makhazine Havzası'nda CBS programı yardımıyla erodobilite dağılım haritası oluşturulması ve diğer topraklar arasındaki ilişkinin belirlenmesine yönelik gerçekleştirdikleri çalışmada, havza topraklarının erodobilite değerlerinin 0.24 ile 0.85 arasında değiştiğini, incelenen toprakların orta ve şiddetli erodobilite olma seviyelerinde olduklarını, özellikle havzanın büyük bir kısmında (\% 71.27) toprakların erodobilite değerlerinin çok yüksek olduğu ve bu durumun da özellikle havza topraklarının bünye bakımından yüksek silt ve ince kum içeriklerinden kaynaklandığını belirtmiş̧lerdir.

\subsection{Erozyon duyarlılık parametreleri ile toprak özellikleri arasında korelasyonu analizi}

Toprak örneklerinin ele alınan özelliklerine yönelik olarak normal dağılım gösterip göstermediğinin tespitinde K-S (KolmogorovSmirnov) testi uygulanmıştır. Yapılan K-S testi sonucu verilerin tamamının normal dağılım göstermediği tespit edilmiş, bu yüzden verilerin korelasyon ilişkisini ortaya koymak için Spearman korelasyonu uygulanmıştır. Çalışma sonucunda, 105 korelasyon çiftinden 70 tanesi istatistiksel olarak anlamlı $(\mathrm{p}<0.05 ; \mathrm{p}<0.01)$ bulunmuştur (Tablo 5). En yükssek pozitif korelasyon ilişkisi KO ile Hİ arasında (0.888) en yüksek negatif korelasyon ilişkisi ise yine $\mathrm{KO}$ ile kil arasında (-1.00) tespit edilmiştir. $\mathrm{N}, \mathrm{P}$ ve $\mathrm{K}$ değerleri arasında $\mathrm{p}<0.01$ düzeyinde önemli pozitif ilişki tespit edilmiştir. Organik madde ile N, P ve K değerleri arasında da pozitif yüksek önemlilik gösteren ilişkiler olduğu görülmüştür (Tablo 5). Toprak kalitesi, toprakların iyi bir yapısal gelişimleri ve verimlilik açısından topraklarda organik madde içeriğinin \% 3'ten daha fazla olması gerekmektedir (Karagöz, 2014).

Toprak örneklerinin kireç miktarı ile EC ve pH arasında $\mathrm{p}<0.01$ düzeyinde pozitif ilişkisi bulunur iken; silt miktarı ile pozitif $(\mathrm{p}<0.05)$ fakat, USLE-K ile yine $p<0.05$ düzeyde ama negatif önemli bir ilişkisi bulunmuştur (Tablo 5). Toprağın erozyona karşı duyarlılığın azalmasına yönelik olan etkenlerden biriside agregatların varlığı ve dayanıklılığıdır. Topraktaki kireç ve organik madde, toprakların agregat oluşumuna önemli katkılar yaptığı, özellikle toprakların agregat stabilitesini arttırarak, erodibilite değerini düşürmekte olduğu, birçok araştırmacı tarafindan belirtilmiştir (Martens, 2000; Plante ve McGill, 2002; Dengiz, 2006; Boix-Fayos ve ark., 2001; Dengiz ve ark., 2013, İmamoğlu ve Dengiz, 2017). Mevcut çalışmada, toprakların kireç ve organik madde içeriklerinin USLE-K değeri ile negatif yönde önemli ilişkiler vermesi, $\mathrm{CaCO}_{3}$ ve organik maddenin agregasyon üzerine yukarıda söz edilen etkilerine atfedilebilir.

Toprakların EC ile toplam N, yarayışlı $\mathrm{P}$, yarayışı $1 \mathrm{~K}, \mathrm{OM}, \mathrm{CaCO}_{3}, \mathrm{pH}, \mathrm{HA}, \mathrm{HI}, \mathrm{DO}$ ve USLE-K arasında pozitif önemlilik gösteren bir ilişki bulunmuştur (Tablo 5). Toprak reaksiyonu toprağın asitlik ve alkalilik derecesinin ifadesi olup

Tablo 5. Toprakların erozyon duyarlılık parametreleri ile bazı fiziksel ve kimyasal özellikleri arasındaki korelasyon analiz sonuçları

\begin{tabular}{|c|c|c|c|c|c|c|c|c|c|c|c|c|c|c|}
\hline & $\mathrm{N}$ & $\mathrm{P}$ & K & $\mathrm{OM}$ & $\mathrm{CaCO}_{3}$ & EC & $\mathrm{pH}$ & Kil & Silt & Kum & HA & $\mathrm{HI}$ & DO & USLE-K \\
\hline $\mathrm{P}$ & $0.357^{* k * k}$ & & & & & & & & & & & & & \\
\hline K & $0.464^{* * k}$ & $0.361^{* *}$ & & & & & & & & & & & & \\
\hline $\mathrm{OM}$ & $0.640^{* *}$ & $0.477^{* *}$ & $0.646^{* *}$ & & & & & & & & & & & \\
\hline $\mathrm{CaCO}_{3}$ & 0.152 & 0.097 & 0.098 & 0.116 & & & & & & & & & & \\
\hline EC & $0.444^{* *}$ & $0.325^{* *}$ & $0.507^{* *}$ & $0.594^{* *}$ & $0.475^{* *}$ & & & & & & & & & \\
\hline $\mathrm{pH}$ & $0.174^{*}$ & -0.064 & $0.199^{*}$ & 0.099 & $0.526^{* *}$ & $0.545^{* *}$ & & & & & & & & \\
\hline Kil & $0-.011$ & -0.107 & $0.162^{*}$ & -0.039 & 0.015 & -0.029 & 0.121 & & & & & & & \\
\hline Silt & 0.122 & -0.001 & $0.312^{* *}$ & $0.163^{*}$ & $0.192^{*}$ & $0.181^{*}$ & $0.234^{* *}$ & $0.386^{* *}$ & & & & & & \\
\hline Kum & -0.041 & 0.066 & $-0.232^{* *}$ & -0.043 & -0.130 & -0.078 & $-0.206^{*}$ & $-0.858^{* *}$ & $-0.742^{* *}$ & & & & & \\
\hline HA & $-0.638^{* *}$ & $-0.458^{* *}$ & $-0.619^{* *}$ & $-0.927^{* *}$ & -0.145 & $-0.603^{* *}$ & -0.136 & 0.157 & $-0.227^{* *}$ & 0.011 & & & & \\
\hline Hİ & $0.288^{* *}$ & $0.288^{* * *}$ & 0.109 & $0.407^{* *}$ & -0.004 & $0.254^{* *}$ & -0.116 & $-0.889^{* *}$ & $-0.256^{* *}$ & $0.740^{* *}$ & $-0.527^{* *}$ & & & \\
\hline DO & $-0.365^{* *}$ & $-0.200^{*}$ & $-0.478^{* * *}$ & $-0.571^{* *}$ & -0.150 & $-0.405^{* *}$ & $-0.260^{* * *}$ & -0.121 & $-0.189^{*}$ & $0.161^{*}$ & $0.524^{* *}$ & -0.100 & & \\
\hline USLE-K & $-0.521^{* *}$ & $-0.376^{* *}$ & $-0.638^{* *}$ & $-0.839^{* *}$ & $-0.167^{*}$ & $-0.521^{* *}$ & $-0.210^{* * *}$ & $-0.369^{* *}$ & $-0.264^{* *}$ & $0.412^{* *}$ & $0.750^{* *}$ & 0.032 & $0.523^{* *}$ & \\
\hline $\mathrm{KO}$ & 0.010 & 0.107 & $-0.162^{*}$ & 0.039 & -0.014 & 0.029 & -0.121 & $-1.00^{* *}$ & $-0.386^{* *}$ & $0.858^{* *}$ & -0.157 & $0.888^{* * *}$ & 0.121 & $0.370^{* *}$ \\
\hline
\end{tabular}


$\mathrm{pH}$ ile ölçülür ve $\mathrm{pH}$ hidrojen iyonları konsantrasyonunun negatif logaritmasıdır (Mater, 1998). Korelasyon sonuçlarına göre; $\mathrm{pH}$ ile toplam $\mathrm{N}$, yarayışlı $\mathrm{K}$, kum ile $\mathrm{p}<0.05$ düzeyinde önemli ilişki gösterirken, $\mathrm{CaCO}_{3}, \mathrm{EC}$, silt ve USLE-K ile $\mathrm{p}<0.01$ düzeyinde önemli ilişkili olduğu belirlenmiştir.

Tekstür toprakta meydana gelen fiziksel ve kimyasal olaylar üzerinde önemli bir faktör olduğu gibi toprağın erozyona karşı duyarlılığında da belirleyici faktördür. Kaba tekstürlü topraklar çoğunlukla az miktarda kil ve organik madde içerirler, ama geçirgenlikleri yüksek oldukları için daha az aşınırlarken; ince tekstürlü topraklar güç aşınırlar, ama aşınınca kolay taşınırlar yani, toprak tekstürü aşınmada olduğu gibi taşınmada da etkilidir (Özdemir, 2002). Tekstürel özellikler arasında yüksek ilişki görülmektedir. Kil ile Hİ arasında negatif $\mathrm{p}<0.01$ düzeyinde önemli ilişki tespit edilmiştir. Aynı zamanda, kum ile Hİ arasında yüksek pozitif ilişki tespit edilmiştir (Tablo 5). Topraktaki kil miktarı arttıç̧a geçirimlilik azalmaktadır. Kil ile USLE-K ve KO arasında negatif önemli ilişki olduğu sonucuna ulaşılmıştır (Tablo 5). Benzer şekilde Demirci ve Yakupoğlu (2013) yaptıkları çalışmada, toprakların kil miktarı ile USLE-K ve KO arsında negatif yönde önemli bir ilişki belirlerken, bazı araştırmacılar (Okatan ve ark., 2000; Mamedov ve ark., 2007) kil fraksiyonu miktarının artışına paralel olarak genel anlamda aşınabilirlik azalmakta olduğunu belirtmişlerdir. Ayrıca, elektrostatik yükü, içerdiği hakim kil mineralinin çeşidi ve tane boyutu gibi özelliklerin yön verdiği agregat oluşumundaki rolü (Bronick ve Lal, 2005) nedeniyle, kil fraksiyonu aşınabilirliği doğrudan etkilemektedir.

Hacim ağırlığı toprakların bünye özelliğine bağlı olarak değişir (Mater, 1998). Korelasyon sonuçlarına göre HA ile silt miktarı arasında negatif $\mathrm{p}<0.01$ düzeyinde önemli ilişki tespit edilmiştir. Hacim ağırlığının toprak fiziksel analiz sonuçları ile $\mathrm{p}<0.01$ düzeyinde ilişki gösterdiği görülmektedir. Ayrıca, toprakların HA özelliğinin bilinmesi kil tipi, toprak sıkışması, toplam porozite, por büyüklük dağılımı, por geometrisi, bünye ve strüktür gibi toprak özellikleri hakkında fikirler vermekte ve çıkarımlar yapılmasına olanak sağlamaktadır (Öztekin ve ark., 2007). Bununla birlikte Hİ, bünye özellikleriyle de önemli ilişki göstermektedir.

Dispersiyon oranı topraktaki doğal agregatların su ile temas ettiğinde çözülme (dispersleşme) derecesinin bir göstergesi olup, 1slanma sonucunda toprak strüktüründeki bozulmayı yansıtmaktadır. $\mathrm{Bu}$ oranının azalması toprakların erozyona karşı dayanıklılıklarını arttırmakta, \% 15'ten küçük orana sahip topraklar erozyona karşı dayanıklı olarak kabul edilmektedir (Lal, 1988). Dispersiyon oran1 ile toprakların kimyasal özellikleri (N, P, K, OM, $\mathrm{EC}$ ve $\mathrm{pH}$ ) arasında negatif yönde yüksek önemlilik saptanmıştır (Tablo 5). Dispersiyon oranı ile fiziksel özellikler arasındaki durum incelendiğinde; toprakların kil içerikleri ile her hangi bir önem düzey göstermezken, silt ve kum içerikleri ile negatif ve pozitif yönde $\mathrm{p}<0.01$ düzeyinde önemli ilişki tespit edilmiştir (Tablo 5). Aşınımı etkileyen en önemli toprak özellikleri; toprağın bünyesi, toprağın strüktürü, hidrolik geçirgenliği ve organik madde kapsamı olarak tanımlanmaktadır (Cebel ve ark., 2013).

USLE-K değerinin korelasyonuna bakıldığında, USLE-K değerinin sadece Hİ ile herhangi bir anlamlı ilişkisi olmadığı, fakat hemen hemen diğer tüm parametrelerle $\mathrm{p}<0.01$ düzeyinde pozitif ve negatif ilişkili olduğu görülmüştür. Özellikle toprakların kil içerikleri ile $\mathrm{p}<0.01 \quad\left(-0.369^{* *}\right)$ düzeyde negatif ilişki belirlenmiştir (Tablo 5). Benzer şekilde, Özdemir ve Gülser (2017) yaptıkları çalışmada, toprakların kil içerikleri ile USLE-K arasında negatif yönde yüksek düzeyde $\left(-0.920^{* *}\right) \quad$ korelasyon ilişkili olduğunu belirlemişlerdir.

\section{Sonuçlar}

$\mathrm{Bu}$ çalışmada, Ilgaz Milli Park alanı içerisinde dağılım gösteren toprakların Evrensel Toprak Kayıp Eşitliğinin alt bileşeni olan toprak aşınım faktörü (USLE-K), DO ve KO gibi bazı aşınabilirlik faktörlerini belirlenmesi ve diğer bazı toprak özellikleriyle ilişkisini olan ilişkisi incelemiştir. Çalışmada ayrıca duyarlılık faktörünün mesafeye bağlı değişkenlik özeliğinin enterpolasyon modeller yardımıyla dağılım haritası üretilmiştir. Buna göre DO için Basit Krigi'nin Küresei modeli uygun olarak belirlenirken USLE-K için IDW enterplasyon modelin 2. kuvveti uygun olarak belirlenmiştir. Ayrıca, KO için ise yine Basit Kriging'in Gaussian modeli uygun olduğu belirlenmiştir.

Araştırma alanı topraklarının çok az bir kısmı DO bakımından literatürlerde sınır olarak ele alına \% 15 değerin altında yani erozyona karşı dayanıklı olarak belirlenirken, alanın büyük kısmı ise DO bakımından erozyona karşı duyarlı olduğu belirlenmiştir. $\mathrm{Bu}$ alanlar özellikle çalışma alanı sınırları içerisinde güney ve güneybatısına doğru ilerledikçe DO değerinin artış gösterdiği belirlenmiştir. Toprakların KO değerleri ise bilindiği gibi bu değer küçüldükçe, toprakların erozyona karşı dayanıklılık derecesi de artmaktadır. KO değerlerinin büyüme trendi alan içerisinde kuzey ve kuzeybatıya doğru gerçekleşmektedir. Her 
iki orandan da anlaşılacağı gibi Ilgaz Milli Park sınırları içerisinde kalan alan içerisinde dağılım gösteren toprakların erozyona karşı dirençlerinin oldukça düşük olduğunu göstermektedir. Bu durum çalışmada diğer bir erodobilite faktörü olan USLE$\mathrm{K}$ ile de doğrulanmış olup, USLE-K değeri üç farklı sınıflama sistemine göre değerlendirilmiştir. Her üç değerlendirme sınıflarına bakıldığında, çalışma alanının yarıdan fazlası çok fazla veya çok yüksek aşınabilir özellikte olduğu görülmektedir.

Sonuç olarak; araştırma alanı toprakların büyük bir kısmı erozyona karşı duyarlılıkları oldukça yüksek oldukları, bu nedenle korumanın önde gelen koşullarından biri erodobilite değerlerini en düşük düzeyde tutmaktır. Bu da toprağın organik madde kapsamını ve hidrolik geçirgenliğini artırıcı ve strüktürünü geliştirici önlemlerin alınması ile mümkün olmasının yanı sıra, üzerinde yer alan bitki örtüsünün tahrip edilmemesidir.

\section{Kaynaklar}

Anonim, 2009. Ilgaz Dağ1 Milli Park1 Ölçekli Uzun Devreli Gelişme Planı. Çevre ve Orman Bakanlığ Doğa Koruma ve Milli Parklar Genel Müdürlüğü Milli Parklar Dairesi Başkanlığı.

Anonymous, 1992. Procedures for Collecting Soil Samples and Methods of Analysis for Soil Survey. Soil Survey Investigations Report, I.U.S. Government Printing Office, Washington D.C., USA.

Anonymous, 1999. Soil Taxonomy. A Basic of Soil Classificationfor Making and Interpreting Soil Survey, U.S.D.A Handbook No: 436, Washington D.C.

Balcı, N., Özyuvacı, N., 1974. Türkiye'nin iki farklı bölgesinde yer alan topraklarda erozyon eğiliminin ana materyal, bak1, arazi kullanma şekli ve örnekleme derinliğine bağlı olarak değişimi. İstanbul Üniversitesi Orman Fakültesi Dergisi, Seri A, 2: 79107.

Belasire, A., Lakhıuili, A., Halima, I., 2017. Soil erodibility mapping and its correlation with soil properties of Oued El Makhazine watershed, Morocco. Journal of Materials and Environmental Sciences, 8(9): 3208-3215.

Blake, G.R., Hartge, K.H., 1986. Bulk Density and Particle Density. In: Methods of Soil Analysis, Part I, Physical and Mineralogical Methods. ASA and SSSA Agronomy Monograph No 9 ( $2^{\text {nd }}$ Ed $)$, Madison, pp. 363-381.

Boix-Fayos, C., Calvo-Cases, A., Imeson, A.C., SorianoSoto, M.D., 2001. Influences of soil properties on the aggregation of some Mediterranean soils and the use of aggregate size and stability as land degradation indicators. Catena, 44(1): 47-67.

Bouyoucos, G.J., 1951. A recalibration of the hidrometer method for making mechanical analysis of soils. Agronomy Journal, 43: 435-438.
Bremner, J.M., Mulvaney, C.S., 1982. Nitrogen-Total. In: A.L. Page, R.H. Miller, D.R. Keeney (Eds.), Methods of Soil Analysis, Part 2, Chemical and Microbiological Properties, $2^{\text {nd }}$ Edition, Agronomy, 9: 595-624.

Bronick, C.J., Lal, R., 2005. Soil structure and management: a review. Geoderma, 124(1-2): 3-22.

Bryan, R.B., 1968. The development, use and efficiency of indices of soil erodibility. Geoderma, 2(1): 5-26.

Cebel, H., Akgül, S., Doğan, O., Elbaşı, F., 2013. Türkiye büyük toprak gruplarının erozyona duyarlılık "K" faktörleri. Toprak Su Dergisi, 2(1): 30-45.

Dangler, E.W., El-Swaify, S.A., Ahuja, L.R., Barnet, A.P., 1976. Erodobility of Selected Hawaii Soils by Rainfall Simulation. Thecnical Report No: ARS-W35, Honululu, Hi., pp. 113.

Demirci, D., Yakupoğlu, T., 2013. Kahramanmaraş-Narlı Ovası topraklarının erozyona duyarlılıkları ile bazı toprak özellikleri arasındaki ilişkiler. Anadolu Tarım Bilimleri Dergisi, 28(1): 33-38.

Dengiz, O., 2006. Comparison of different irrigation methods based on the parametric evaluation approach. Turkish Journal of Agriculture and Forestry, 30(1): 21-29.

Dengiz, O., Kızılkaya, R., Erkoçak, A., Durmuş, M., 2013. Variables of microbial response in natural soil aggregates for soil characterization in different fluvial land shapes. Geomikrobyology Journal, 30(2): 100107.

Dengiz, O., Sağlam, M., Özaytekin, H.H., Başkan, O., 2013. Weathering rates and some physico-chemical characteristics of soils developed on a calcic toposequences. Carpathian Journal of Earth and Environmental Sciences, 8(2); 13-24.

Ding, Y., 2011. Research on the spatial interpolation methods of soil moisture based on GIS. International Conference on Information Science and Technology, 26-28 March, Nanjing, China, pp. 709-711.

Elges, H.F.W.K., 1985. Problem soils in south AfricaState of the art. The Civil Engineer in South Africa, 27: 347-353.

Eraslan, S., İmamoğlu, A., Coşkun, A., Saygın, F., Dengiz, O., 2016. İnebolu Havzası topraklarının erozyon duyarlıliklarını belirlenmesinde agregat ve strüktür stabilite durumları, arazi örtüsü ile olan ilişkileri. Uluslararası Coğrafya Sempozyumu, 13-14 Ekim, TÜCAUM, Ankara, s. 779-794.

Erol, A., Babalık, A.A., Sönmez, K., Serin, N., 2009. Isparta-Darıderesi Havzas1 topraklarında erozyona duyarlılığın arazi kullanım şekillerine bağlı değişimi. Süleyman Demirel Üniversitesi Orman Fakültesi Dergisi, Seri: A, 2: 21-36.

Gülçur, F., 1974. Toprağın Fiziksel ve Kimyasal Analiz Metodları. İstanbul Üniversitesi Orman Fakültesi Yayın No. 201, Kutulmuş Matbaası, İstanbul.

Gülser, C., Ekberli, İ., Candemir, F., Demir, Z., 2016. Spatial variability of soil physical properties in a cultivated field. Eurasian Journal of Soil Science, 5(3): 192-200. 
Johnston, K., Hoef, M., Krivoruchko, K., Lucas, N., 2001. Using ArcGIS Geostatistical Analyst. ESRI, New York, USA.

Irmak, A., 1968. Toprak İlmi. İstanbul Üniversitesi Yayın No: 1268, Orman Fakültesi Yayın No: 121, Becid Basımevi, İstanbul.

İlay, R., Kavdır, Y., 2018. Gökçeada topraklarının erozyon duyarlılı̆̆1. Anadolu Tarım Bilimleri Dergisi, 33(2): 68-72.

İmamoğlu, A., Dengiz, O., 2017. Determination of soil erosion risk using RUSLE model and soil organic carbon loss in Alaca catchment (Central Black Sea region, Turkey). Rendiconti Lincei, 28(1): 11-23.

Kacar, B., 1994. Bitki ve Toprağın Kimyasal Analizleri: III. Toprak Analizleri. Ankara Üniversitesi Ziraat Fakültesi, Eğitim Araştırma ve Geliştirme Vakfi Yayınları No: 3, Ankara.

Kanar, E., Dengiz, O., 2015a. Madendere Havzas1 topraklarında arazi kullanım/arazi örtüsü ile bazı erozyon duyarlılık indeksleri arasındaki ilișkinin belirlenmesi. Türkiye Tarımsal Araştırmalar Dergisi, 2(1): 15-27.

Kanar, E., Dengiz, O., 2015b. Madendere Havzasında potansiyel erozyon risk durumunun iki farkl1 parametrik model kullanarak belirlenmesi ve risk haritalarının oluşturulması. Türkiye Tarımsal Araştırmalar Dergisi, 2(2): 123-134.

Karaatl1, M., 2010. Verilerin düzenlenmesi ve gösterimi. Ş. Kalaycı (Ed.), SPSS uygulamalı çok değişkenli istatistik teknikleri, Asil Yayın, Ankara, s. 2-47.

Karagöktaş, D., Yakupoğlu, T., 2014. Erozyon araştırma sahasina dönüştürülmesi planlanan bir alanda aşınabilirlik ve toprak özellikleri arasındaki ilişkiler. Toprak Bilimi ve Bitki Besleme Dergisi, 2(1): 6-12.

Karagöz, A., Tercan, E., Erpul, E., Türkeş, M., Dengiz, O., Doğan, O., Öztaş, T., 2017. Türkiye Çölleşme Modeli. Orman ve Su İşleri Bakanlığı, Ankara.

Karagöz, K., 2014. Yarasa gübresinin tarımda kullanımı. Alinteri, 27(B): 35-42.

Klute, A., Dirksen, C., 1986. Hydraulic conductivity and diffusivity: Laboratory methods. In: A. Klute (Ed.), Methods of Soil Analysis-Part 1: Physical and Mineralogical Methods, American Society of Agronomy, Madison, pp. 687-734.

Lal, R., 1988. Soil Erosion Research Methods. Soil and Water Conservation Society, Netherland.

Mallants, D., Mohanty, B.P., Jacques, D., Feyen, J., 1996. Spatial variability of hydraulic properties in a multilayered soil profile. Soil Science, 161(3): 167-181.

Mamedov, A.I., Beckmann, S., Huang, C., Levy, G.J., 2007. Aggregate stability as affected by polyacrylamide molecular weight, soil texture, and water quality. Soil Science Society of America Journal, 71(6): 1909-1918.

Martens, D.A., 2000. Plant residue biochemistry regulates soil carbon cycling and carbon sequestration. Soil Biology and Biochemistry. 32(3): 361-369.

Mater, B., 1998. Toprak Coğrafyası. Çantay Kitapevi, İstanbul.
Okatan, A., Yüksel, A., Reis, M., 2000. KahramanmaraşAyvalı Barajı Kızıldere yağış havzasında toprakların erozyon eğilim değerlerinin hidrofiziksel toprak özelliklerine bağlı olarak değișimi. Fen ve Mühendislik Dergisi, 3(1): 28-42.

Olsen, S.R., Cole, C.V., Watanable, F.S., Dean, L.A., 1954. Estimation of available phosphorus in soils by extraction with sodium bicarbonate. USDA Circular 939. U.S Government Printing Office, Washington D.C.

Özdemir, N., 1998. Toprak Fiziği. Ondokuz May1s Üniversitesi Yayınları, Ders Kitabı No: 30, Samsun.

Özdemir, N., 2002. Toprak ve Su Koruma. Ondokuz Mayıs Üniversitesi, Ziraat Fakültesi Ders Notu, Samsun.

Özdemir, N., Gülser, C., 2017. Clay activity index as an indicator of soil erodibility. Eurasian Journal of Soil Science, 6(4): 307-311.

Öztaş, T., 1996. Eğimli bir arazide erozyonla kaybolan toprak derinliğindeki değişimin Kriging analizi ile belirlenmesi. Tarım-Çevre İlişkileri Sempozyumu, "Doğal Kaynakların Sürdürülebilir Kullanımı", 1315 Mayis, Mersin, s. 327-335.

Öztekin, T., Cemek, B., Brown, L., 2007. Pedotransfer functions for the hydraulic properties of layered soils. Gaziosmanpaşa Üniversitesi Ziraat Fakültesi Dergisi, 24(2): 77-86.

Özyazıcı, M.A., Dengiz, O., Aydoğan, M., Bayraklı, B. Kesim, E., Urla, Ö., Yıldız, H., Ünal, E., 2015. Orta ve Doğu Karadeniz Bölgesi tarım topraklarının bazı makro ve mikro bitki besin maddesi konsantrasyonları ve ters mesafe ağırlık yöntemi (IDW) ile haritalanmas1. Artvin Coruh Üniversitesi Orman Fakültesi Dergisi, 16(2): 187-202.

Özyazıc1, M.A., Dengiz, O., Aydoğan, M., Bayraklı, B., Kesim, E., Urla, Ö., Yıldız, H., Ünal, E., 2016. Orta ve Doğu Karadeniz Bölgesi tarım topraklarının temel verimlilik düzeyleri ve alansal dağılımları. Anadolu Tarım Bilimleri Dergisi, 31(1): 136-148.

Pauwels, J.M., Aelterman, J., Gabriels, D., Bollinne, A., Rosseau, P., 1980. Soil erodibility map of Belgium. In: M. De Boodt and D. Gabriels (Eds.), Assessment of erosion, Chichester, J. Wiley, pp. 193-201.

Plante, A.F., McGill, W.B., 2002. Soil aggregate dynamics and the retention of organic matter in laboratory-incubated soil with differing simulated tillage frequencies. Soil and Tillage Research, 66(1): 79-92.

Prosdocimi, M., Jordan, A., Tarolli, P., Keesstra, S., Novara, A., Cerda, A., 2016. The immediate effectiveness of barley straw mulch in reducing soil erodibility and surface runoff generation in Mediterranean vineyards. Science of the Total Environment, 547: 323-330.

Renard, K.G., Foster, G.R., Weesies, G.A., McCool, D.K., Yoder, D.C., 1997. Predicting soil erosion by water: A guide to conservation planning with the revised universal soil loss equation (RUSLE). U.S. Department of Agriculture, Agriculture Handbook, 703, Government Printing Office, SSOP, Washington, DC. 
Richards, L.A., 1954. Diagnosis and Improvement of Saline and Alkalin Soils. U.S. Department of Agriculture, No: 60, Riverside, USA.

Schaetzl, R., Anderson, S., 2005. Soils: Genesis and Geomorphology. Cambridge University Press.

Sönmez, K., 1982. Van yöresi topraklarında fosforik asit triple süperfosfat ve ahır gübresinin agregasyon, agregat stabilitesi ve kırılma değeri üzerine etkileri. Profesörlük takdim tezi (Basılmamış), Atatürk Üniversitesi Ziraat Fakültesi, Erzurum.

Sönmez, K., 1994. Toprak Koruma. Ankara Üniversitesi Ziraat Fakültesi Yayınları No: 169, Erzurum.

Sönmez, K., Özdemir, N., 1988. Iğdır Ovası yüzey topraklarının bazı fiziksel ve kimyasal özellikleri ile strüktürel dayanıklılık ölçütleri arasındaki ilişkiler. Atatürk Üniversitesi Ziraat Fakültesi Dergisi, 19 (1-4): 155-163.

Tunçay, T., Dengiz, O., 2016. Chemical weathering rates and geochemical-mineralogical characteristics of soils developed on heterogeneous parent material and toposequence, Carpathian Journal of Earth and Environmental Sciences, 11(2); 583-598.

Türkeş, M., 2013. İklim Verileri Kullanılarak Türkiye'nin Çölleşme Haritası Dokümanı Hazırlanması Raporu. Birinci Bask1, T.C. Orman ve Su İşleri Bakanlığı, Çölleşme ve Erozyonla Mücadele Genel Müdürlüğü Yayını, Ankara.

Ülgen, N., Yurtsever, N., 1995. Türkiye Gübre ve Gübreleme Rehberi (4. Bask1). T.C. Başbakanlık Köy
Hizmetleri Genel Müdürlüğü Toprak ve Gübre Araştırma Enstitüsü Müdürlüğ̈̈ Yayınları, Genel Yayın No: 209, Teknik Yayınlar No: T.66, Ankara.

Van Wambeke, A.R., 2000. The Newhall Simulation Model for Estimating Soil Moisture \& Temperature Regimes. Department of Crop and Soil Sciences, U.S. Departmanet of Agriculture, Ithaca, N.Y. Washington, DC.

Wallis, J.R., Stewan, L., 1961. Erodibility of some california Midlands soils related to their cations exchange capacity. Journal of Geophysical Research, 66(4): 1225-1230.

Wilding, L., 1985. Spatial variability: Its documentation, accommodation and implication to soil surveys. D.R. Nielsen and J. Bouma (Eds.), Soil spatial variability, Pudoc, Wageningen, The Netherlands, pp. 166- 194.

Wischmeier, W.H., Smith, D.D., 1978. Predicting Rainfall Erosion Losses: A Guide to Conservation Planning. Agricultural Handbook No: 537, United States Department of Agricultural Science and Education Administration, Agricultural Research, Washington, DC.

Yakupoğlu, T., Gündoğan, R., Dindaroğlu, T., Kaya, Z., 2017. Effects of land conversion from native shrub to pistachio orchard on soil erodibility in an arid region. Environmental Monitoring and Assessment, 189(11): 588

Yıldız, N., Akbulut, Ö., Bircan, H., 1999. İstatistiğe Giriş. Aktif Yayınevi, Erzurum. 